Interlinkages between External Debt Financing, Credit Cycles and Output Fluctuations in Emerging Market Economies

Akhilesh K Verma and Rajeswari Sengupta

Indira Gandhi Institute of Development Research, Mumbai April 2020 


\title{
Interlinkages between External Debt Financing, Credit Cycles and Output Fluctuations in Emerging Market Economies
}

\author{
Akhilesh K Verma and Rajeswari Sengupta
}

Email(corresponding author): akhilesh@igidr.ac.in

\begin{abstract}
We examine the role of external debt financing $(E D F)$ in shaping the credit cycle and output fluctuations in nine major emerging economies. We show that sharp fluctuations in EDF flows are significantly associated with credit surge and stop episodes in emerging market economies (EMEs). However the association is asymmetric in nature - a stop episode in EDF flows is more likely to bring about a credit stop episode compared to an EDF surge episode. We extend our framework to analyze the joint spillover of EDF flows and credit cycles on business cycle fluctuations in these EMEs. We find that EDF flows and credit together have a strong association with output growth. After dividing the sample into EDF surge and stop phases, we find evidence of asymmetric spillover of credit on output growth. Credit decline during EDF stop episode leads to a larger decline in GDP growth relative to the impact of an increase in credit growth during EDF surges. Our analysis points to the vulnerability of credit cycles of EMEs to the sharp movement in EDF flows which in turn is largely synchronized with external financing conditions. The strong negative spillover of EDF stop phases on the business cycle is a cause of concern for policymakers in EMEs who seek to insulate their economies from such external shocks
\end{abstract}

Keywords: External debt finance, Credit cycle, Dynamic panel GMM, Business cycle

JEL Code: E47, E51, F34, F65, G15 


\title{
Interlinkages between External Debt Financing, Credit Cycles and Output Fluctuations in Emerging Market Economies*
}

\author{
Akhilesh K Verma ${ }^{\dagger}$ \\ Rajeswari Sengupta
}

\begin{abstract}
We examine the role of external debt financing (EDF) in shaping the credit cycle and output fluctuations in nine major emerging economies. We show that sharp fluctuations in EDF flows are significantly associated with credit surge and stop episodes in emerging market economies(EMEs). However the association is asymmetric in nature - a stop episode in EDF flows is more likely to bring about a credit stop episode compared to an EDF surge episode. We extend our framework to analyze the joint spillover of EDF flows and credit cycles on business cycle fluctuations in these EMEs. We find that EDF flows and credit together have a strong association with output growth. After dividing the sample into EDF surge and stop phases, we find evidence of asymmetric spillover of credit on output growth. Credit decline during EDF stop episode leads to a larger decline in GDP growth relative to the impact of an increase in credit growth during EDF surges. Our analysis points to the vulnerability of credit cycles of EMEs to the sharp movement in EDF flows which in turn is largely synchronized with external financing conditions. The strong negative spillover of EDF stop phases on the business cycle is a cause of concern for policymakers in EMEs who seek to insulate their economies from such external shocks.
\end{abstract}

JEL classification: E47, E51, F34, F65, G15

Keywords: External debt finance, Credit cycle, Dynamic panel GMM, Business cycle

*. Acknowledgment : We would like to thank Prof. Ashima Goyal and Prof. Subrata Sarkar for their helpful comments and feedback. All remaining errors are our own.

†. PhD student, IGIDR, Mumbai (Email id - akhilesh@igidr.ac.in)(西)

$\ddagger$. Assistant Professor, IGIDR, Mumbai(Email id - rajeswari@igidr.ac.in) 


\section{Introduction}

Two significant linkages in the context of emerging market economies (EMEs) have gained considerable attention in the past as well as in recent times; the role of external debt flows in shaping credit cycles and the relationship between the credit cycle and the business cycle ${ }^{1}$. Reinhart and Rogoff (2009) documents that external debt booms typically precede domestic credit and debt booms which in turn, lead to banking crises in EMEs. Such a banking crisis typically doubles the size of public debt, leads to a recession that lasts for two years on average and results in a five percent decrease in output from the historical trend level (Reinhart and Rogoff 2010).

These links have recently gained importance in EMEs as they attracted substantial external debt financing during the previous two decades (figure 1). As shown in the figure, the proportion of debt flows in total international portfolio inflows has consistently risen during the previous decade. Several factors such as increased financial globalization, easy access to global liquidity and gradual market deregulation are key determinants of the rising trends in external debt flows (Mohanty and Rishabh 2016). The share of relatively volatile external debt instruments, external debt securities and local currency debt, have also increased post-GFC. This could be a cause of concern for these economies in the face of global recovery, increase in global long term rates after a sustained period of lower interest rates and easy global financing conditions (Shin 2014; Feyen et al. 2012; Pena et al. 2015).

On the other hand, EMEs have also observed a significant rise in their domestic lending during the last two decades (figure 2). The credit to GDP ratio has consistently remained above the 100 percent level during this period. The relative share of credit to the non-financial sector has significantly risen. This might indicate economic expansion and investment activity or the existence of a credit bubble. Didier et al. (2016) points out that the average output growth of EMEs has declined post-GFC and remained below their long-term (1990-2008) average ${ }^{2}$. The characteristics of this slowdown, as partly cyclical and partly structural, typically vary at the country level and they also depend upon the integration of a particular country with the world economy.

1. Credit cycle consists of two phases; credit boom and bust. The credit boom is typically defined by a phase in which the cyclical component of private sector credit to GDP is more than 1.65 times its standard deviation in at least one year or that in which an annual rate of credit to GDP ratio is above 20 percent (Ohnsorge and Yu 2016; Bakker et al. 2012). An average credit boom lasts for 1.7 years and a maximum of up to 5 years.

2. The report also documents several external and domestic factors responsible for this dynamic such as low world commodity prices, weak global trade, a slowdown in domestic productivity growth and policy uncertainty in EMEs. 
In the face of increased financial globalization of EMEs during the previous two decades, it is likely that cyclical fluctuations in output growth could have been reinforced by transitory external debt flows and its association with the domestic credit cycle. Given this background, the main theme of this chapter is to explore the interlinkages among external debt financing (EDF), credit cycles and output fluctuations in EMEs.

This paper poses two key questions. First, we analyze the role of EDF flows in facilitating credit surge and stop episodes in EMEs ${ }^{3}$. Second, we examine the the joint impact of external debt financing and the credit cycle to characterize the business cycle in EMEs in addition to the impact during phases of surge and stop episodes in EDF flows.

Figure 1: International investment portfolio composition for EMEs

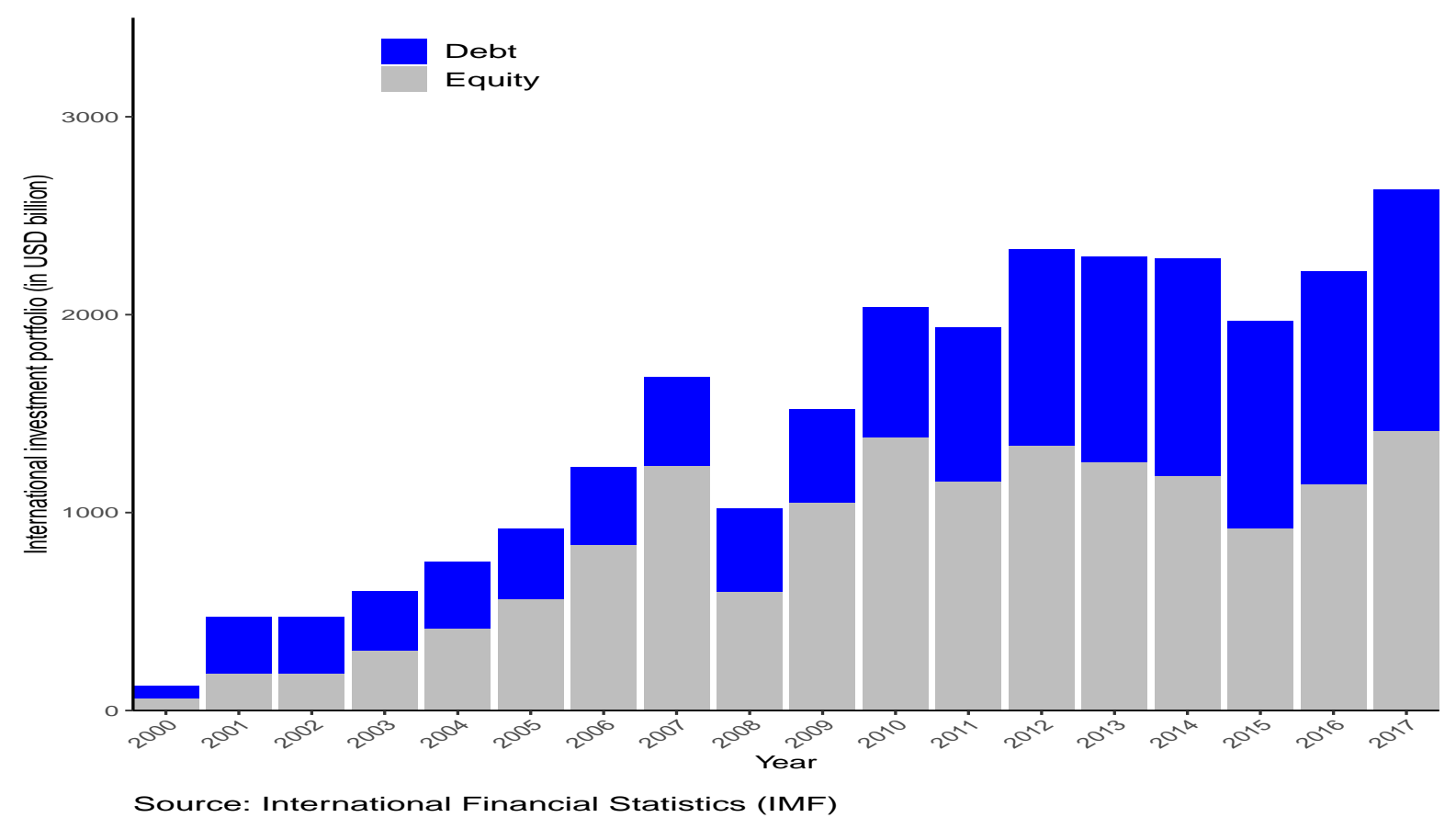

The first part of the interlinkage i.e. the relation between EDF and credit boom-bust cycle is of major importance for EMEs due to their deeper credit markets, relatively underdeveloped capital market and their dependence on external financing to smoothen consumption and investment needs. At the compositional level of EDF, foreign currency credit to non-financial corporates has increased in EMEs. This exposes them to exchange rate risk and other market risks (Chui et al. 2016). Despite stronger corporate bond issuance since 2010, external debt

3. Surge and stop episodes are defined as the economic phases that exceed the levels of key macroeconomic variables justified by economic fundamentals or the potential level (Forbes and Warnock 2012; Sula 2010). In the context of this chapter, it indicates a sudden and large increase or reduction in cross border flows and credit growth. We provide a detailed discussion on the calculation of surge and stop episode in section 2.3. 
securities accounted for only 19 percent of the credit to the corporate sector in 2015 and the rest of the credit to corporates continues to be financed through bank loans.

The structure of corporate financing is relatively unbalanced in EMEs; access to the bond market is generally restricted to a few large firms while smaller firms can access financing through the conventional banking sector. Large firms' easy access to the bond market with longer maturity and lower costs reflects the distortionary financial structure and the concentration of such debt in fewer EMEs' corporates. Such unbalanced distribution of financing may choke the entire financial system in the case of external or domestic shocks affecting larger firms or key sectors in the economy.

Figure 2: Credit composition for EMEs as \% of GDP
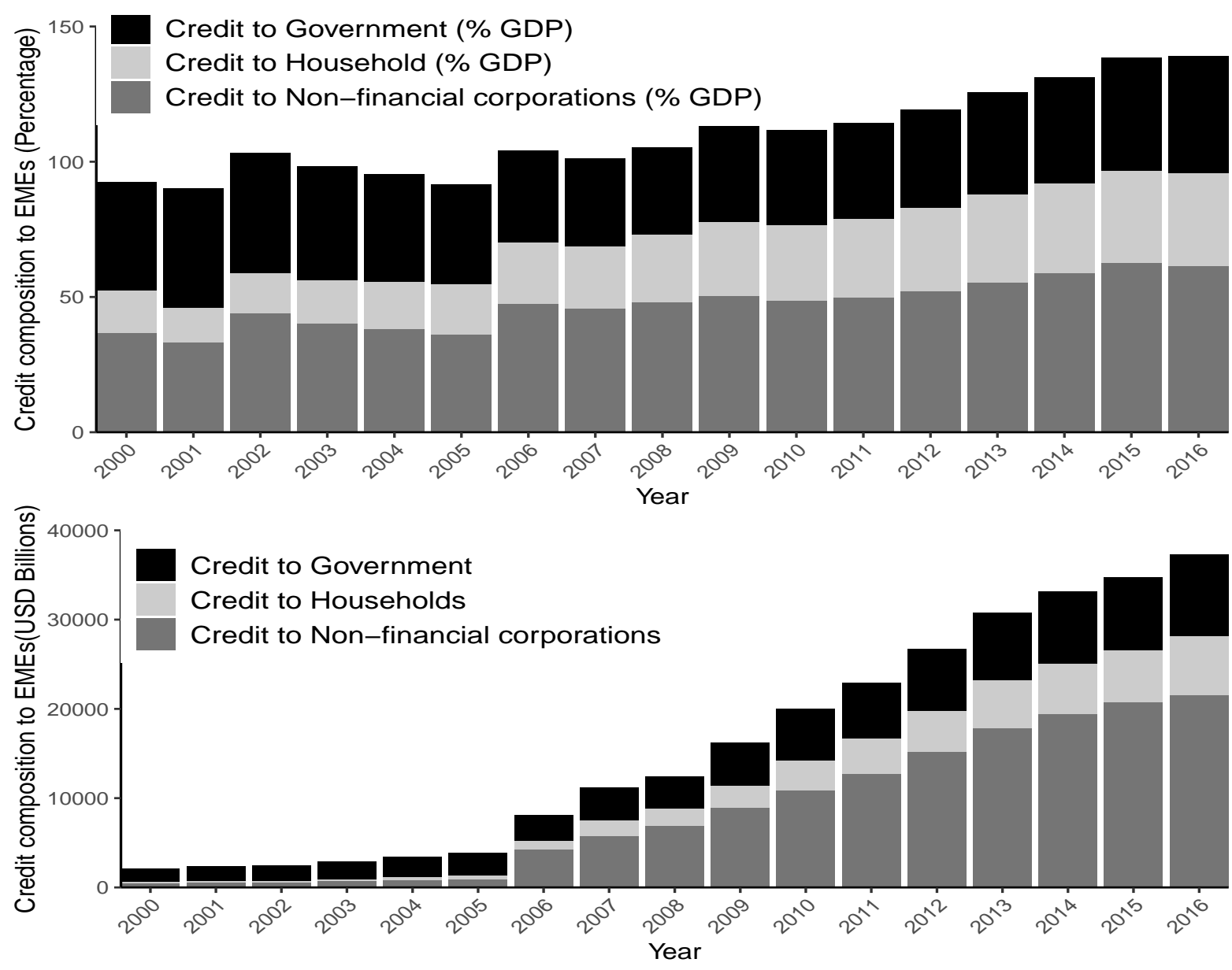

Source: Bank of International Settlements database

Portfolio debt flows have facilitated excessive credit growth followed by widespread economic consequences for EMEs such as economic slowdown, banking crisis, higher interest rates, real exchange rate appreciation and inflation (Baskaya et al. 2017; Forbes and Warnock 2012; Tornell 
and Westermann 2002; Tornell et al. 2003). During the credit boom phase in the economy, GDP growth rate increased by 2 percent, investment growth rate doubles and current account deteriorates by one percent (Bakker et al. 2012).

GDP growth rapidly rises before credit booms and decrease before they end (Mendoza and Terrones 2008; Elekdag and $\mathrm{Wu}$ 2013; Arena et al. 2015). Faster credit growth leads to a deeper recession and slower recoveries subsequently. Sixty percent of credit booms are followed by an economic slowdown and one third is followed by the banking crisis. In certain cases, a high level of private sector credit to GDP (80-100 percent) ratio is not found to be growth-enhancing for emerging market and developing economies (EMDEs) (Cecchetti et al. 2011). Calderon and Kubota (2012) explores the association between an increase in gross debt inflows and the credit cycle in a large sample of countries and find a strong and positive relationship between the two variables.

Credit boom (or rapid credit growth) is a key determinant and an early warning indicator of macroeconomic and financial distress in an economy. For example, credit to the private sector rose 10 percent above its long-term trend before GFC (Drehmann et al. 2015; Ohnsorge and Yu 2016). Gourinchas and Obstfeld (2012) shows that the banking crisis was preceded by a deviation of credit to the private sector by 9 percent from its long-term trend in Central and Eastern European countries ${ }^{4}$. Credit to the non-financial private sector, during a credit boom phase, increases around $6 \%$ on average. The boom phases generally last for less than two years followed by deleveraging over the next three years. After the credit boom subsides, within three years, one-third of the credit boom phase is followed by a deleveraging period and private sector credit to GDP ratio reduces by more than one standard deviation below trend.

A deleveraging period typically lasts for about 1.5-4 years and has a strong association with current account improvement and GDP contraction: 2 percent below the long-term trend of real GDP. During a contraction episode followed by a credit boom phase, private sector credit decreased to 35 percent or reduced by almost 2 percent of GDP per year on average (World Bank 2016).

Credit booms are not always followed by an economic crisis. However, they are highly likely to translate into a debt overhang phase if they were majorly financed externally. This can restrict long-term growth or follow the stagnant business cycle for a sustained period and lead

4. These credit thresholds are not always accurate in indicating impending macroeconomic crises. As a counterexample, credit to the private sector exceeded the earlier threshold for a few energy-exporting EMDEs in 2015 (Ohnsorge and Yu 2016). Similarly, firm leverage in a few EMEs was near or above the level that preceded the East Asian financial crisis (1997). 
to accumulation of stressed assets in the economy. In such a situation, the economy may need to conduct a balance sheet cleaning for a prolonged period to further abate debt overhang and face the consequent economic slowdown (Lo and Rogoff 2015; Buttiglione et al. 2014). Such features of the credit boom-bust phases and their impact on economic fluctuations reinforce the strong association of the credit cycle with the business cycle and make it specifically relevant for EMEs due to their vulnerability to external and domestic shocks.

The credit cycle and the business cycle, the second part of the interlinkage, are strongly correlated and their fluctuations can affect the domestic growth cycle subsequently (Azariadis 2017). This link signifies the interaction between the financial and real sectors of an economy which has recently received considerable attention among researchers particulary after GFC (2008). In the context of EMEs, this relationship gains more importance due to the dominance of the banking sector in EMEs' financial market and its role in order to maintain a sustainable high growth path. Large volatility in their credit market due to external shocks can play a vital role in determining the business cycles of these economies. Several studies have shown that financial shocks significantly affect the dynamics of real variables in the economy (Khan and Thomas 2013; Perri and Quadrini 2018). Bahadir and Gumus (2016) provides evidence that private credit is strongly correlated with the business cycle of EMEs. It further shows that business credit and household credit have a differential impact on the business cycle.

Low global interest rates and borrowing costs are commonly associated with rapid credit growth in EMEs (Ohnsorge and Yu 2016). Given the link between EDF and the credit cycle, a future rise in global borrowing costs would further increase the debt service burden that may affect the credit cycle and business cycle of EMEs. It would primarily make external borrowing costlier for banks and corporates and possibly strain their balance sheets. The deleveraging process among banks also affects the growth trajectory of EMEs that are already struggling to adjust with weak global demand post-GFC. The evidence also points out that financing conditions have begun to tighten in emerging market and developing economies due to gradual recoveries in advanced economies as capital flows reduced by 18 percent and external bond issuance shrank by 22 percent between 2014 and 2015 (Ohnsorge and Yu 2016).

The questions on the relationship between EDF flows, credit growth and output growth are related to two main strands of the literature.

The first strand looks into the role of global financial conditions in determining cross border flows, credit cycles and economic imbalances in EMEs. As discussed earlier, EMEs experience 
economic expansion during easy liquidity conditions and credit boom and contract in the negative phase. Excess cross border flows fueled by easy liquidity conditions typically precede credit booms: an early warning indicator of a sudden stop and financial crisis ${ }^{5}$ (Kaminsky and Reinhart 1999; Kaminsky et al. 2005; Eichengreen and Arteta 2002; Schularick and Taylor 2012). Credit booms generally increase liquidity risks and share of non-performing loans during global liquidity flows reversal which puts the financial system in a vulnerable position. Agosin and Huaita (2012) shows that the probability of a sudden stop episode increases as the boom phase lengthens in an economy: the probability doubles if the boom phase remains for three years.

Large capital inflows can also impact total national debt and budget balance in the economy which can put the economy in distress during liquidity tightening (Calvo et al. 1996; Kaminsky et al. 2003). Aguiar and Gopinath (2007) theoretically demonstrate that output fluctuation in the form of the business cycle is strongly linked with current account reversals or a sudden stop in emerging market economies. However, Chari et al. (2005) shows that a sudden stop or lack of access to global capital markets would not necessarily lead to a decline in the GDP of an economy. They further deduce that the GDP of the economy would increase in the face of international liquidity tightening or a sudden stop due to frictions in the economy.

Episodes of cross border flow volatility are more recurrent in EMEs relative to developed countries. This has unintended consequences for the business cycle fluctations (Broner and Rigobon 2006). On average, an emerging economy experiences capital flow volatility episodes at least once every decade (Edwards et al. 2007; Rothenberg and Warnock 2006). A number of empirical evidence point that 'not all types of cross border flows are the same' which is most recently documented by Forbes and Warnock (2012). The episodes of cross border flows are broadly divided into two categories; equity led and debt-led. Debt-led episodes of extreme capital flows are more frequent than equity led episodes. This is one of our motivations to choose EDF flows, a subset of capital flows, to explore their linkages with the credit boom/bust phase and business cycle fluctuations in this chapter.

Another global factor, US dollar depreciation, is a significant determinant of cross border flows and an indicator of tightening global liquidity conditions (Bruno and Shin 2015a, 2015b). During the financial boom, the foreign currency-denominated component of credit increases which may have strong repercussions on the balance sheet of banks and firms during the bust phase (Borio et al. 2011).

5. Sudden stop episode refers to a negative phase in which growth in capital inflows drops at least a standard deviation below average in the last five years and at least two standard deviations below the prior average in one quarter. 
The second strand of literature focuses on the association between credit growth and macroeconomic outcomes in the context of EMEs. The role of the financial intermediary in driving the business cycle is emphasized in the theoretical literature. They drive the business cycle through several channels: financial frictions, information asymmetry and collateral constraints (Bernanke and Gertler 1995; Kiyotaki and Moore 1997; Gertler and Kiyotaki 2010). The expected correlation between the sudden-stop and the business cycle remains strong due to the interaction of the frictions in a given economy with global liquidity markets. Countries with financial frictions are more likely to be susceptible to a sudden stop in the form of capital flows reversal and a larger decline occurs in those industries that are more sensitive to financial frictions and those that benefit less from price changes to tradable sectors. Several features of financial frictions are commonly found in EMEs such as capital controls, micro and macroprudential regulations and incomplete financial markets.

Rapid credit expansion leads to output expansion, a large current account deficit and real exchange rate appreciation (Tornell and Westermann 2002; Bahadir and Gumus 2016). Credit shocks significantly contribute to output decline and accounts for a fifth of business cycle fluctuations (Meeks 2012). However, there are limited studies that explore dynamic inter-dependencies of external debt financing (a component of capital flows), the credit cycle and the business cycle in one framework with a focus on the time period marked by GFC (2008) . Avdjiev et al. (2017) explore only one part of this relationship; the role of external debt in shaping the credit cycle in EMEs and show that a higher share of cross-border loans in the form of bonds is most likely to cause credit surge and that a lower share of inter-bank lending was associated with the credit bust phase.

Given this background, issues related to EDF, credit cycle, and the business cycle have remained a focus area in the literature but their interlinkages during EDF surge and stop episodes in EMEs are relatively less explored. EDF flows, being a subset of capital flows, have played a crucial role to affect credit cycle and output fluctuations. We use a sample of 10 major EMEs for the period of 2000-2016 to study the relationship. We ask two key questions in this chapter. First, what is the role of EDF surge/stop episodes in determining the credit surge/stop phase in EMEs? Second, what is the joint effect of fluctuations in EDF flows and credit growth on output growth for the entire sample period. We further separate the sample period into EDF surge and stop episodes for any differential impact of EDF flows and credit growth on business cycle fluctuations.

We construct surge and stop episodes of credit and EDF flows in EMEs to complement the 
analysis. Our findings are as follows. First, we find that EDF surge/stop episodes are strongly linked with credit surge/stop episodes using a panel multinominal logit model framework. Interestingly, a stop episode in EDF flows is more likely to bring about a credit stop phase in EMEs compared to the role of EDF flow surges in characterizing credit surge episodes. In the second part of our analysis, we employ a dynamic panel GMM to estimate the impact of EDF flows and credit growth on output expansion. In this setup, we find that the combined impact of credit growth and EDF flows on output growth is larger compared to their individual impact, indicating a strong interaction effect of credit growth and EDF flows on business cycle fluctuations in EMEs.

We further extend the analysis by dividing the sample into EDF surge and stop episodes and find that credit growth significantly affects output growth during EDF surges whereas the effect is insignificant during EDF stops. This indicates that since an EDF stop is more likely to bring about a credit stop in the economy; output growth largely remains unaffected by credit growth during such phases. Further, we investigate the potential presence of an asymmetric impact of credit growth on output growth in the two phases: EDF surge and stop episodes. We find that credit decline during an EDF stops episode contracts GDP growth by a larger magnitude compared to the impact of an increase in credit growth on GDP growth. We summarize the results as follows - First, the credit cycles in EMEs are highly sensitive to the surge/stop phase of EDF flows which points to the dependency of credit cycles on the fluctuations in global financing conditions: a key determinant of EDF flows. Second, EDF flows and credit growth jointly affect the business cycle in EMEs. EDF stop episodes bring about a larger economic contraction if credit declines during these episodes and the spillover magnifies due to likely credit stops. Whereas the impact remains moderate if credit rise during EDF surge episodes.

The rest of this paper is structured as follows. Section 2 describes data, descriptive statistics and several other dimensions of the dataset used for analysis. Section 3 provides a detailed discussion of the methodologies used to analyze the questions posed in this chapter. Section 4 discuss the key results and robustness checks respectively. Section 5 concludes.

\section{Data}

We have used quarterly data on a sample of nine EMEs from 2000Q1-2016Q4 for the empirical analysis of the questions posed in this chapter. The countries included in the sample are Brazil, Chile, India, Indonesia, Mexico, Malaysia, Russia, South Africa, and Thailand. The 
main data sources are International Debt Statistics (BIS), Locational Bank Statistics (BIS), International Financial Statistics (IMF) and Thomson Reuters. The key macroeconomic variables for the analysis are GDP growth, EDF flows, and credit to the non-financial sector of EMEs. We further detrend GDP growth series using (CF) filtering method and estimated GDP cycle following Christiano and Fitzgerald (2003). The detrended series mainly captures output expansion/contraction which we use for robustness checks of results.

Further, EDF flows are calculated by the sum of cross border bank loans (CBL flows) and external debt securities issuance (EDS flows) denominated in foreign currency. We take GDP growth rate as a key dependent variable. Other macroeconomic controls for the analysis include domestic factors such as CPI inflation, short-term interest rate (91 days treasury bill rate or money market rate), industrial production and nominal bilateral exchange rate. We capture global determinants by the volatility index (VIX) for global uncertainty and time period dummy for the post-crisis period following Cetorelli and Goldberg (2011) and Shin (2014). VIX captures US equity market volatility and closely captures risk perception or risk aversion in global financial market that is likely to impact global liquidity transmission to EMEs. In the section below, we provide descriptive statistics of the dataset and related key correlation plots.

\subsection{Data overview}

Table 1: Summary statistics for sample EMEs

\begin{tabular}{|c|c|c|c|c|c|c|}
\hline \multirow[t]{2}{*}{ Variables } & \multicolumn{2}{|c|}{ Full sample (2000-16) } & \multicolumn{2}{|c|}{ Pre GFC (2000-08) } & \multicolumn{2}{|c|}{ Post GFC (2009-16) } \\
\hline & Mean & Std. dev. & Mean & Std. dev. & Mean & Std. dev. \\
\hline EDF (USD billion) & 2.365 & 14.246 & 1.241 & 6.093 & 3.557 & 19.408 \\
\hline External debt sec (USD billion) & 0.889 & 2.825 & 0.193 & 1.832 & 1.627 & 3.443 \\
\hline CB loans(USD billion) & 1.572 & 14.258 & 1.048 & 5.639 & 2.112 & 19.491 \\
\hline Credit (USD billion) & 53.212 & 174.776 & 24.921 & 67.204 & 81.752 & 235.098 \\
\hline GDP cycle (CF) & 0.000 & 0.047 & 0.005 & 0.041 & -0.005 & 0.052 \\
\hline Nominal GDP growth & 0.095 & 0.150 & 0.143 & 0.135 & 0.050 & 0.149 \\
\hline Long-term interest rate & 7.101 & 3.277 & 7.507 & 3.438 & 6.727 & 3.080 \\
\hline Short-term interest rate & 5.117 & 3.275 & 5.729 & 3.674 & 4.450 & 2.624 \\
\hline Exchange rate (pct change) & 0.722 & 5.386 & 0.535 & 5.465 & 0.920 & 5.302 \\
\hline IIP growth & 2.801 & 5.919 & 4.300 & 5.237 & 1.316 & 6.183 \\
\hline Inflation & 5.065 & 4.185 & 5.689 & 4.647 & 4.384 & 3.497 \\
\hline US long-term interest rate & 3.540 & 1.234 & 4.538 & 0.700 & 2.452 & 0.612 \\
\hline VIX & 20.149 & 8.086 & 21.084 & 8.852 & 19.160 & 7.065 \\
\hline
\end{tabular}

Note: Table 1 lists key macroeconomic variables that capture domestic fundamentals of EMEs and external variables that affect EDF transmission to EMEs.

Table 1 summarizes basic data for our sample economies divided into two periods marked by GFC. The average EDF is three times larger in the post GFC period with increased volatility 
relative to the pre-GFC period. At its compositional level, average EDS flows have substantially increased compared to the CBL flows post-GFC (2008). Such a rapid increase in EDS issuance post-GFC is in line with similar dynamics captured by Shin (2014). The paper termed this phase as the 'second phase of global liquidity' in which EDS issuance picked up faster then CBL due to search for higher yields and deleveraging among global banks during this period. Nevertheless, the volatility of EDF flows has clearly increased post-crisis which could be risky for EMEs' financial stability because of its spillover to the real economy.

In addition to this, credit to non-financial sectors has tripled post-GFC with rising volatility, coinciding with the increased EDF flows to EMEs. Nominal GDP growth dropped to almost one-third post-GFC from its level pre-GFC, indicating a higher output loss. De-trended GDP (GDP cycle) on average has become negative post-crisis indicating incomplete recovery of EMEs after the crisis. First and second moment based trends of EDF flows and credit growth provide a useful background to explore the potential impact of this association on short-run output growth in the context of EMEs, the main theme which we intend to explore in this chapter. Other domestic macroeconomic variables such as short-term interest rates, long-term interest rates, and IIP growth have observed a downward trend after the crisis.

In the same period, VIX and long-term US interest rates, a proxy for external factors affecting global liquidity, have marginally declined. Lower and less volatile VIX points to a relatively stable global financial environment whereas a lower long-term US interest rate incentivizes liquidity transmission toward EMEs in search of higher yields. Given the dynamics of key macroeconomic variables, we present moving-average plots below to examine potential interlinkages among EDF, credit and output fluctuations which a key theme of this chapter. 


\subsection{Data trends in EDF flows, credit and GDP cycle}

Figure 3: Moving correlation between EDF and Credit

— 12-quarter moving correlation between EDF and credit
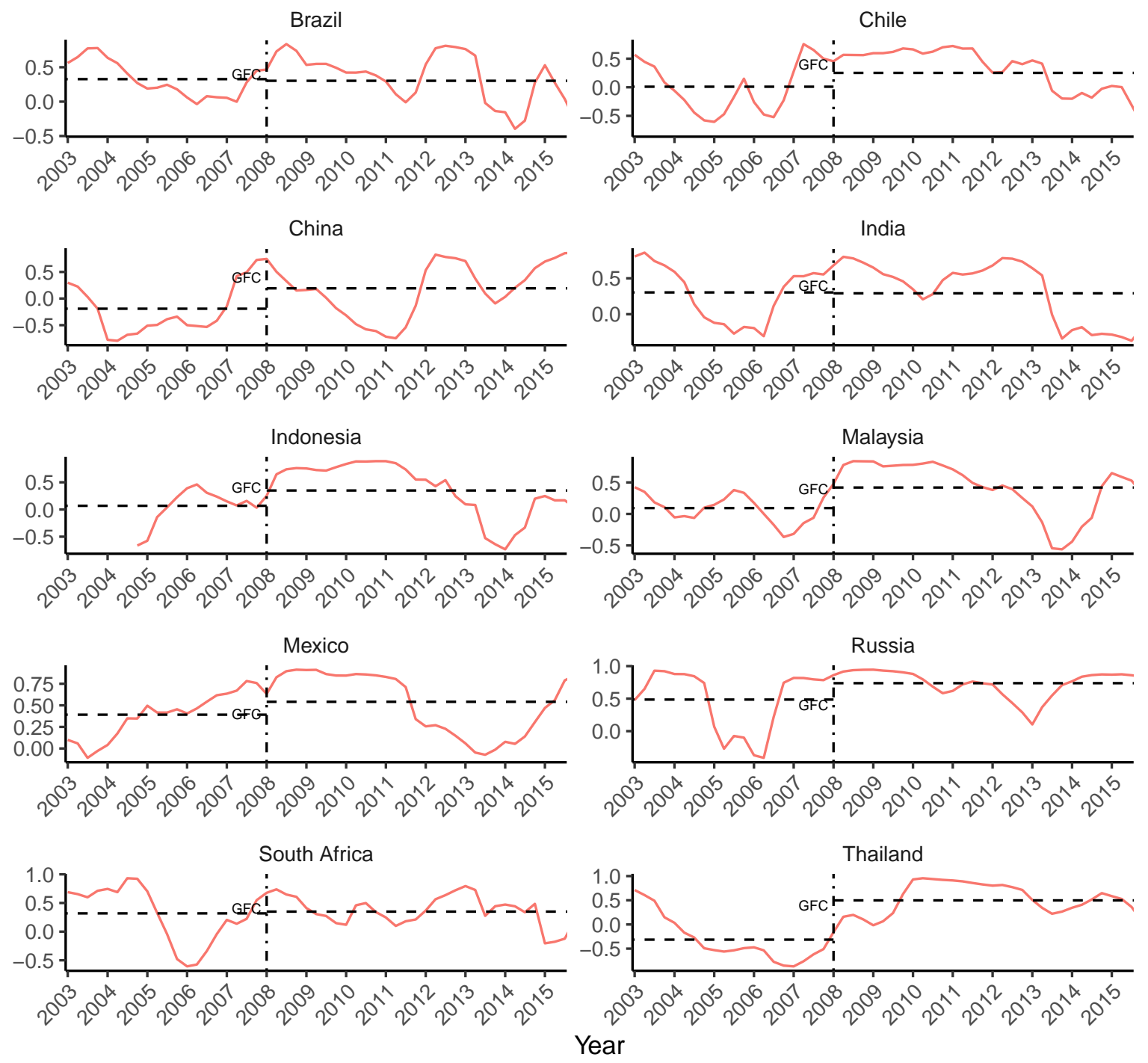

Source: Author's own calculation

Figure 3 demonstrates the first part of the interlinkage, the relation between EDF and credit for each sample EME through a 12 quarter moving correlation ${ }^{6}$. For most sample EMEs, the correlation remains transitory for the sample period and they experience relatively weaker correlation except India, Mexico and Russia. However, the correlation has increased in the post-GFC era for countries like Malaysia, Mexico, Russia and Thailand suggesting that the

6. Moving correlation presents the correlation coefficient calculated between the two data sets for all points within a particular time window which is 12 quarters in our case. For the correlation plot, the time window shifts along with the data and the correlations are calculated at every fixed time interval. Moving correlation mainly describes how the relationship between two variables changes over time 
crucial role of EDF flows has played to fuel rapid credit expansion during this period.

Figure 4 shows the moving co-relation between credit and GDP growth. We find a relatively higher correlation for most of the EMEs, unlike the previous case. The figure also demonstrates that credit growth and output growth are closely related to our sample EMEs. This is generally true for countries with underdeveloped financial markets that exhibit a significant dependence on credit to drive economic growth. This exercise provides us a crucial backdrop to analyze the interlinkages of EDF flows, credit and output expansion which is potentially transitory in nature. Moreover, we explore this interlinkage through estimations in a broader framework controlling for domestic and external factors affecting EMEs.

Figure 4: Moving correlation between credit and GDP growth

\section{- 12-quarter moving correlation between credit and GDP growth}
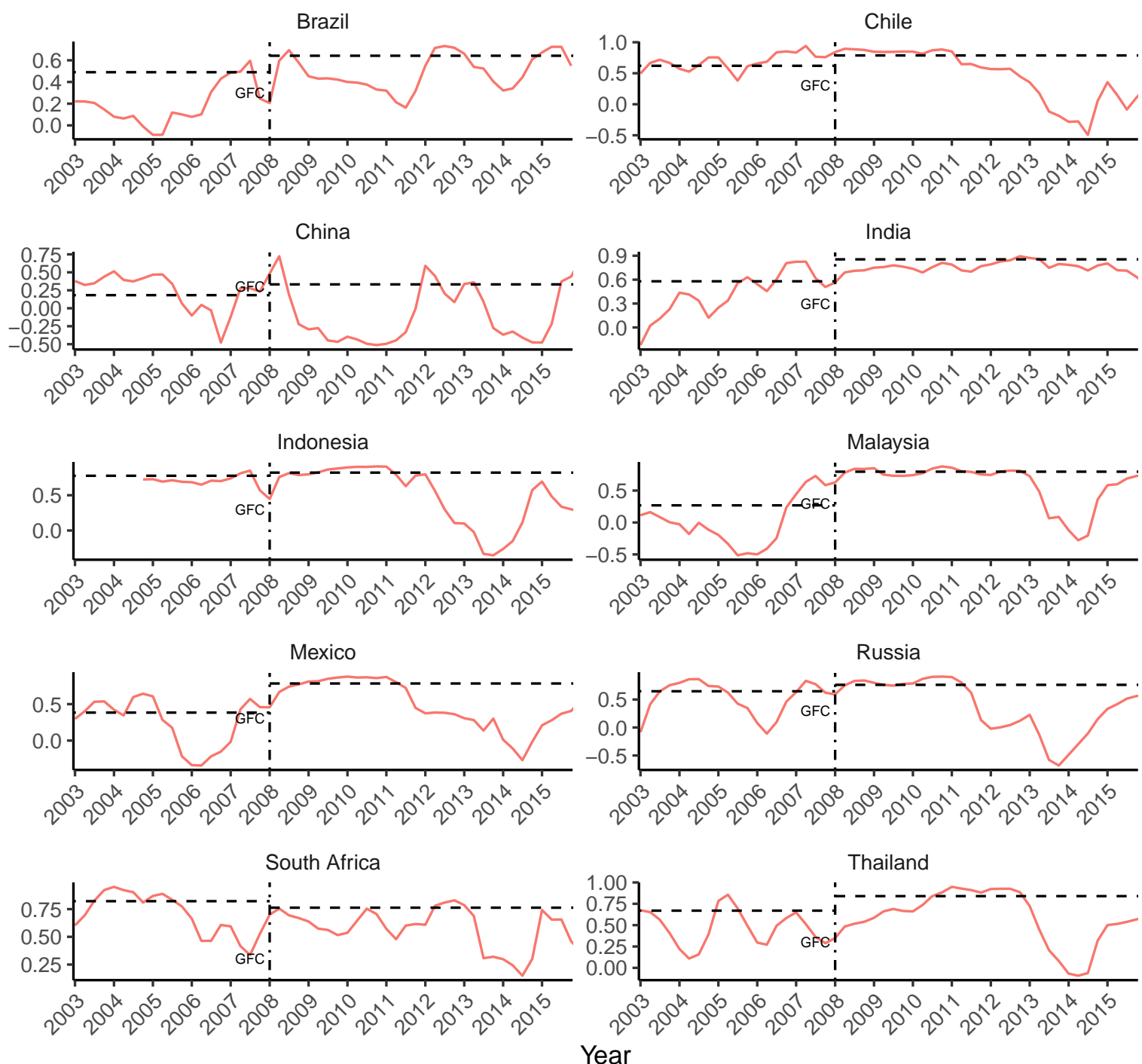

Source: Author's own calculation 
To establish the role of EDF in shaping the credit cycle in emerging economies, we first calculate surge and stop episodes in EDF flows and total credit the following section. We expect to find potential leads and lags between surges/stops between EDF flows and credit growth through this exercise.

\subsection{Identification method to capture surge and stop episodes of credit and EDF}

We have used the methodology provided by Forbes and Warnock (2012) to identify surge and stop episodes in EDF and credit in sample EMEs. Surge episodes are defined by a sharp increase in a given variable whereas stop episodes correspond to a quick decline. In the case of credit, calculation of surge/stop episodes follows two steps. First, calculate 4 quarter moving sum of the total credit $\left(\mathrm{TC}_{t}\right)$ and compute annual changes in $\mathrm{TC}_{t}$ :

$$
\begin{gathered}
T C_{t}=\Sigma \text { Total Credit } t-i ; \quad t=1,2 \ldots N \\
\Delta T C_{t}=T C_{t}-T C_{t-4} ; \quad t=5,6 \ldots N
\end{gathered}
$$

Further, we compute the rolling mean and standard deviation of $\Delta T C_{t}$ over the last five years. A 'credit surge' episode occurs when $\Delta T C_{t}$ increases more than one standard deviation above its rolling mean provided that there is one quarter in which $\Delta T C_{t}$ increases at least one and a half standard deviation above is rolling mean. The computation of 'credit stop' follows

the symmetrically opposite approach. A time period is defined as a 'credit stop' when $\Delta T C_{t}$ decreases more than one standard deviation below its rolling mean given that there is at least one quarter in which $\Delta T C_{t}$ decreases one and a half standard deviation below its rolling mean. Similarly, we have used this method to calculate episodes of 'EDF surge' and 'EDF stop' using total EDF flows for each EME.

Figures 5 and 6 demonstrate the surge and stop episodes for EDF and credit for sample EMEs. We observe mixed episodes of lead and lag between EDF and credit at a county level comparison. We have identified 27 periods of credit surges and 21 periods of credit stop episodes for sample economies. Similarly, we have also found 29 periods of EDF surges and 14 EDF stop episodes. India, Chile, India, and South Africa experienced more frequent credit surge episodes whereas Brazil, Mexico, and South Africa observe the most credit stops for the sample period. EDF surges are similarly more frequent in Chile, China, Indonesia and Thailand whereas EDF 
stops are less frequent in the sample EMEs. We also find clear evidence of co-incidence of surge/stop episodes between EDF and credit flows for most of the countries including Brazil, India, Indonesia, Malaysia, Russia, and Thailand ${ }^{7}$.

Figure 5: Credit surge and stop episodes

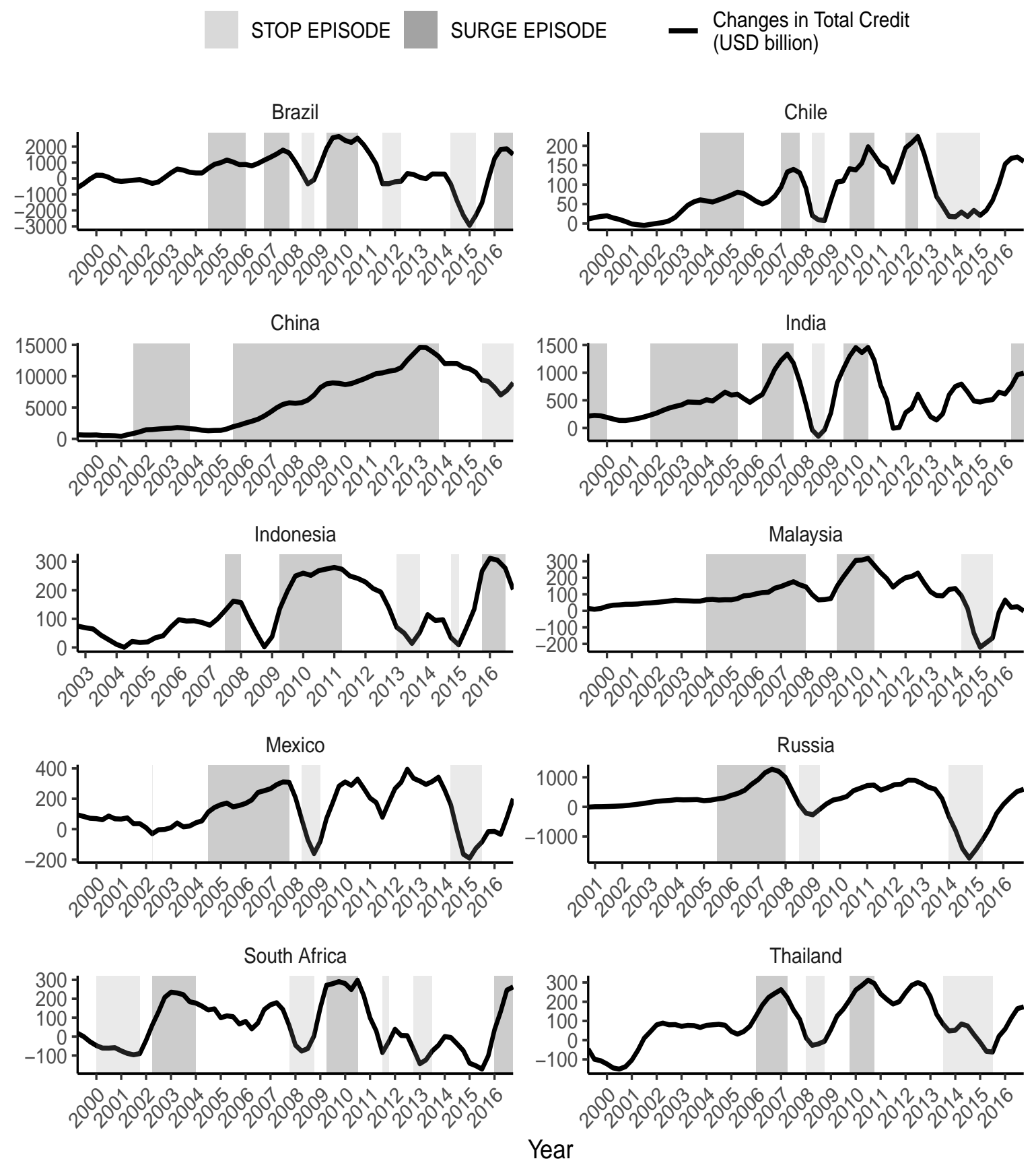

Source: Author's own calculation

The association of surge/stop episodes between EDF and credit provides a useful backdrop that

7. See the Appendix section for further details on the time periods of the surge and stop episodes for EDF and credit in tables A.3, A.4, A.5 and A.6. 
EDF flows play a major role in characterizing the credit cycles in EMEs.

Figure 6: EDF surge and stop episodes
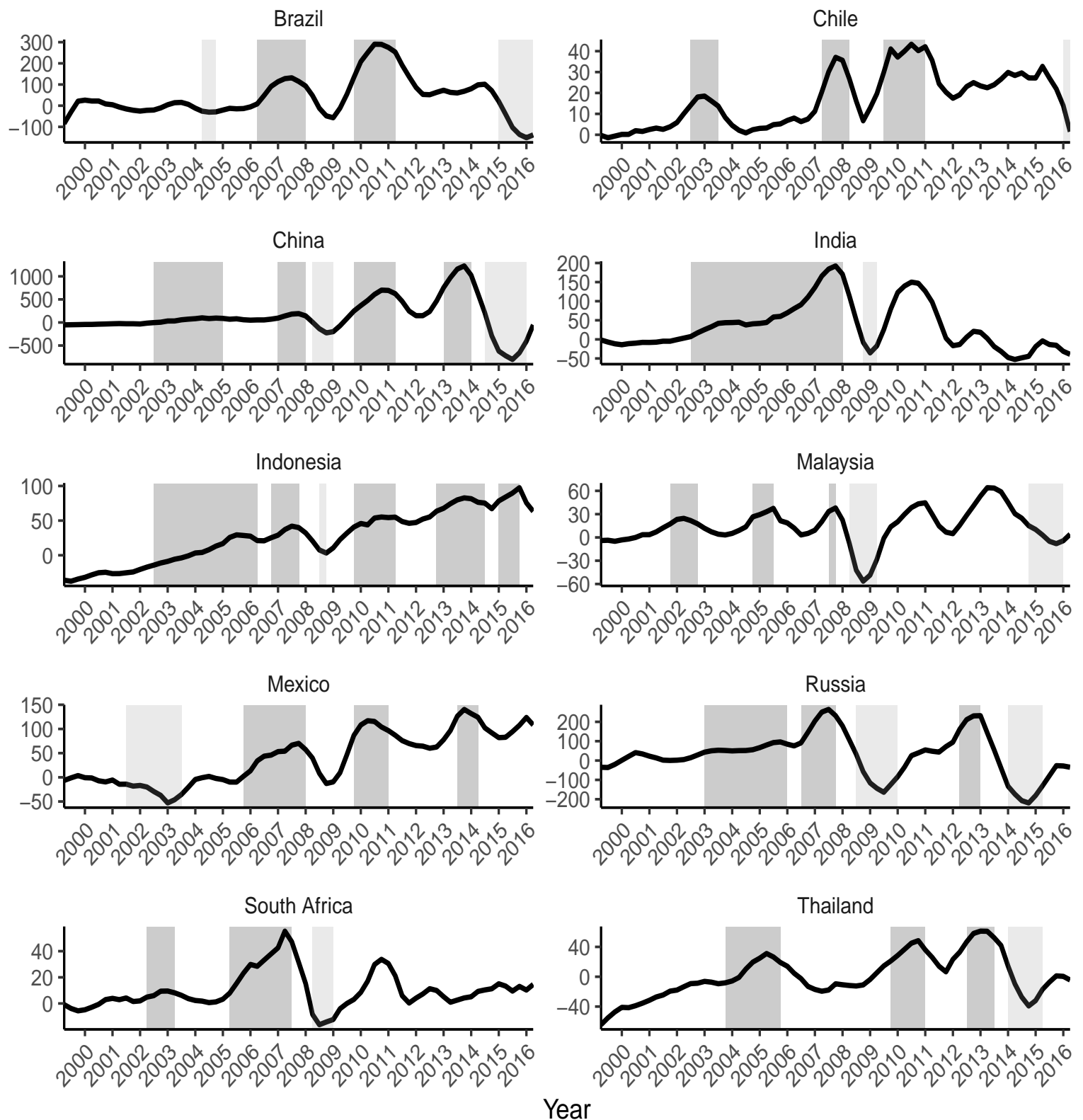

Source: Author's own calculation

\section{Empirical strategy}

Our empirical methodology to analyze the inter-relationship among EDF, the credit, and the business cycle is divided into two parts. First, we employ a panel multinominal logit model to 
estimate the association between EDF surge/stop and credit surge/stop episodes. Specification of the model is as follows -

$$
\operatorname{Pr}\left(\left(y_{i t}>k / \kappa x_{i t}, \mu_{i}\right)=\Phi\left(x_{i t} \beta+\mu_{i}-\kappa_{k}\right) \quad i=1,2 \ldots n, \quad t=1 \ldots T\right.
$$

where $i$ and $t$ denote countries and time respectively, $\mu_{i}$ 's are identical and independently distributed as $\mathrm{N}\left(0, \sigma_{\mu}^{2}\right)$ and $\kappa$ is a set of cut-off points and $\Phi($.$) is the standard normal distribution$ function. The model can be expressed in the form of a latent linear response where observed ordered response is obtained from a latent continuous variable -

$$
y_{i t} *=x_{i t} \beta+\mu_{i}+\epsilon_{i t}
$$

The errors follow a standard normal distribution and are independent of $\mu_{i}$. In our case, the dependent variable $y_{i t} *$ consists of three cases; credit surge, credit stop and no surge/no stop. For the estimation purposes, it is coded as 1 when there is a surge episode, 0 for no surge/no stop episode and -1 for a stop episode experienced by the EME. Credit surge and credit stop episodes are the comparison group in our set up and no stop/no surge episode is taken as the reference group (base outcome) in the model specification. The key explanatory variable in the model is a surge and stop dummy for EDF flows and no surge/stop in EDF flows becomes the reference category. Other key macroeconomic control variables in the model specification are IIP growth rate, nominal exchange rate, inflation, the volatility index (VIX) and post-crisis time dummy variable. The estimating equation in our case becomes -

$$
\begin{aligned}
\text { Credit } \left.^{*} \text { (stop / surge / no surge or stop }\right)= & \beta_{1}(\text { EDF stop time dummy })+ \\
& \beta_{2}(\text { EDF surge time dummy }) \\
& + \text { controls }+\mu_{i}+\epsilon_{i t}
\end{aligned}
$$

As the final output from the logit model estimation, we have reported a relative risk ratio (RRR) in the results section. RRR is captured by $e^{\beta}$ where $\beta$ is the estimated parameter given in equation (3). RRR coefficient of a variable is interpreted as how the risk of the outcome being in the comparison group relative to the risk of the outcome being in the reference group changes with a particular variable in question. $\mathrm{RRR}>1$ indicates that the risk of the outcome being in the comparison group relative to the risk of the outcome being in the reference group increases as variable increases. Whereas $\mathrm{RRR}<1$ points out that the risk of the outcome being in the 
comparison group relative to the risk of the outcome being in the reference group decreases as variable increases. For our analysis, it translates to an interpretation of how changes in EDF flows affect the possibility of the credit cycle to be in a surge or stop period relative to no surge/no stop episode.

In the second part of our analysis, we estimate a dynamic panel model to explore inter-linkages of EDF, credit and GDP growth. This estimation is alternatively known as Arellano-Bond estimator which is implemented in STATA (Arellano and Bond 1991; Roodman 2015). The model specification is as follows -

$$
\begin{gathered}
y_{i t}=\alpha_{0}+\alpha_{1} y_{i, t-1}+\beta x_{i t}+\text { controls }+\epsilon_{i t} \\
\epsilon_{i t}=\mu_{i}+\nu_{i t} \\
E\left(\mu_{i}\right)=E\left(\nu_{i t}\right)=E\left(\mu_{i}, \nu_{i t}\right)=0
\end{gathered}
$$

where $i$ denotes countries, $t$ denotes time and $\mu_{i}$ is the country fixed effect. A key reason why we chose this model for the second part of our analysis was that it controls for endogeneity among variables which is a recurrent feature of a macroeconomic model setup. We have used the difference GMM estimation technique to control for endogeneity and country-level fixed effects. This method further allows for orthogonal differences method that uses future observations while doing first differences and increases the numbers of observations for estimations which is highly useful in an unbalanced panel dataset. To capture the asymmetric impact of credit growth on output growth, we modify the model specification as follows -

$$
y_{i t}=\alpha_{0}+\alpha_{1} y_{i, t-1}+\left(\beta_{2}+\beta_{2, x} D_{t}\right) x_{i t}+\text { controls }+\mu_{i}+\nu_{i t}
$$

where $D_{t}$ is 1 when $x_{i t}$ is positive and 0 otherwise. From the model given above, $\left(\beta_{2}+\beta_{2, x}\right)$ captures the impact on $y_{i t}$ when $x_{i t}$ is positive and $\beta_{2}$ captures the impact when $x_{i t}$ is negative. $\beta_{2, x}$ is measure of asymmetric exposure in this setup.

Alternatively, Lin (2011) shows that previous model setup is also equivalent to the specification given as -

$$
y_{i t}=\beta_{0}+\left(\theta^{-} x_{i t}^{-}+\theta^{+} x_{i t}^{+}\right)+\text {controls }+\mu_{i}+\nu_{i t}
$$

where $x_{i t}$ is divided into two components as follows $-x_{i t}^{-}=\min \left(0, x_{i t}\right)$ and $x_{i t}^{+}=\max \left(x_{i t}, 0\right)$. It 
is evident from the comparison of equations (7) and (8) that $\beta_{2}$ is equal to $\theta^{-}$and $\beta_{2, x}$ is equal to $\left(\theta^{+}-\theta^{-}\right)$. To capture the asymmetry in model equation (7), the null hypothesis that the impact of $x_{i t}$ is symmetric i.e. $H_{0}: \theta^{+}=\theta^{-}=\theta$ and the alternative hypothesis is $H_{1}: \theta^{+} \neq \theta^{-}$. Since model specification given by equation (7) and equation(8) are equivalent, we have employed the latter specification within the dynamic panel setup for a cleaner interpretation (in the later part of our analysis).

We conduct the estimation in two phases here. First, we use the entire sample data to analyze the role of EDF flows and credit flows in influencing the business cycle in EMEs. The dependent variable is nominal GDP growth and the key explanatory variable is credit flows and EDF flows and their interaction variable in addition to macroeconomic control variables including CPI inflation, nominal exchange rate, VIX (a proxy for global uncertainty) and post-crisis time dummy (controls for time period pre and post GFC). This set up can be used o explain the individual impact of credit and EDF flows on nominal GDP growth on average and further provide evidence on the existence of a combined on nominal GDP growth through the interaction of EDF and credit flows. The estimating equation becomes -

$$
\begin{aligned}
G D P_{i t}= & \alpha_{0}+\alpha_{1} G D P_{i, t-1}+\beta_{2} E D F_{i t}+\beta_{3} \text { credit }_{i t} \\
& \beta_{4} E D F_{i t} * \text { credit }_{i t}+\text { controls }+\mu_{i}+\epsilon_{i t}
\end{aligned}
$$

In the latter part, we divide the sample into EDF surge and stop episodes and repeat the exercise to analyze the differential impact of credit growth during the two phases. Further, we modify the previous dynamic model set up to explore the asymmetric impact of credit flows during EDF surge and stop episodes. To capture the asymmetric impact of credit flows on nominal GDP growth, we divide the variable into its positive and negative components using the setup discussed in equation 8 above. In this case, the estimating equation becomes -

$$
\begin{aligned}
G D P_{i t}= & \alpha_{0}+\alpha_{1} G D P_{i, t-1}+\beta_{2} E D F_{i t}+\beta_{3}\left(\text { credit }_{i t}>0\right) \\
& \beta_{4}\left(\text { credit }_{i t}<0\right)+\text { controls }+\mu_{i}+\epsilon_{i t}
\end{aligned}
$$

We present empirical evidence in the next section based on the estimation strategy discussed here. 


\section{Empirical results}

We discuss the empirical analysis in two parts. First, we discuss the role of EDF cycles in characterizing credit cycles in EMEs. We choose this setup to explore to what extent EDF flows characterize and amplify domestic credit cycles for sample economies since they are closely linked with global liquidity conditions and are strong channels of risk transmission. In the second part of the analysis, we explore the inter-linkages between EDF flows, credit and output growth. For the baseline model, we estimate the impact of EDF and credit flows on output growth in EMEs for the entire sample period. This setup is helpful to demonstrate the individual and combined role of EDF and credit in output growth indicating a strong interaction effect on the business cycle of EMEs.

We further extend the analysis by separating the sample period into two phases; EDF surge and stop episodes. The main purpose of dividing the analysis into two episodes is to analyze if credit affects the business cycle (output growth) differently during EDF surge and stop episodes. We initially estimate the impact of credit growth on GDP growth during the EDF surge and stop episodes to demonstrate the presence of any differential impact in the two phases. Finally, to substantiate any asymmetric impact of credit on output growth, we estimate a modified model with credit divided into two subparts; credit increase or creit decline. Since the existing literature documents that the expansion and contraction of credit can have distinct impact on the business cycle, we attempt to quantify the impact of credit increase/decrease on output during EDF surge and stop episodes and find strong supporting evidence for the asymmetric spillover of credit growth on the business cycle.

\subsection{EDF surge/stop episode and credit cycle}

Table 2 represents estimated relative risk ratios (RRR) from the multinomial logit model specified by equation 3. In the model specification, EDF surge and EDF stop are key explanatory variables that affect credit surge and stop episodes. As mentioned earlier, no surge/stop in credit is the reference category in this specification whereas credit surge and credit stop is the comparison group.

RRR values $>1$ means that the risk of outcome falling in the reference category increases as the variable increases whereas $\mathrm{RRR}<1$ means otherwise. 
Table 2: Multinominal logit model (Relative risk ratios)

\begin{tabular}{lcc}
\hline \hline & Credit_stop & Credit_surge \\
\hline EDF surge & $0.292^{* *}$ & $2.644^{* * *}$ \\
& $(-2.62)$ & $(4.36)$ \\
EDF stop & $3.513^{* * *}$ & 0.506 \\
& $(3.32)$ & $(-1.54)$ \\
IIP growth & $0.876^{* * *}$ & 1.033 \\
& $(-4.17)$ & $(1.56)$ \\
$\Delta$ Exchange_rate & $1.048^{*}$ & $0.869^{* * *}$ \\
& $(2.08)$ & $(-5.08)$ \\
Inflation & $1.123^{*}$ & 0.933 \\
VIX & $(1.96)$ & $(-1.67)$ \\
& 1.024 & 1.024 \\
Post_GFC period & $(1.22)$ & $(1.56)$ \\
& $8.018^{* * *}$ & 1.028 \\
Constant & $(4.94)$ & $(0.13)$ \\
& $0.0152^{* * *}$ & 0.364 \\
\hline \hline Observations & $(-4.67)$ & $(-1.88)$ \\
\hline \hline Exponentiated coefficients; $t$ statistics & in parentheses \\
& $650,{ }^{* *} p<0.01,{ }^{* * *} p<0.001$ & \\
&
\end{tabular}

The results in the table emphasize that the probability of credit surges strongly increases during EDF surges whereas EDF stops strongly incentivize credit stops in EMEs. The relative risk of occurrence of credit stop increases by a factor of 3.513 due to EDF stops whereas the relative risk of occurrence of credit surge increases by a factor of 2.644 due to an EDF stop. In other words, EDF flow stop episodes are more influential in bringing about credit stop phases than the EDF surges in characterizing credit surges. We also find that the linkages between stop episodes are relatively stronger post-GFC since the post-crisis time dummy is significantly stronger in this case (RRR coefficient is 8.018). Moreover, credit stops have become highly sensitive to the EDF stop phase in the post-GFC era which is not the case with the surges.

Results also show that an EDF surge strongly discourages credit stops in EMEs since the RRR coefficient for EDF surges is less than 1 (0.292) and significant. The results remain robust to the addition of domestic and global macroeconomic variables controlling for domestic economic cycles (IIP growth rate, inflation, exchange rate and inflation), international liquidity flows and uncertainty (VIX and post crisis dummy). The results also indicate that higher industrial production decreases the probability of a credit stop whereas depreciating exchange rate and 
higher inflation positively impact credit stop episodes in case of EDF stops. However, only exchange rate decline (depreciation) matters during EDF surges, it discourages credit surge during an EDF surge (RRR coefficient is 0.869).

The results derive two clear lessons from the strong linkages between EDF surge/stop episodes, which may be the outcome of global liquidity transmission and yield search, and credit cycles. First, global liquidity transmission through EDF flows is a key channel that shapes credit cycles in the EMEs. Moreover, an extreme movement in global financing may have strong links with the credit conditions in positive and negative directions, however, the impact is stronger on the negative side. The asymmetric synchronization of EDF flows and credit cycles also point to the presence of the 'global financial cycle' as documented by Rey $(2015)^{8}$. EDS boom/bust phases typically have strong linkages with global financing conditions and its spillover to domestic credit cycles which can further contribute to business cycle fluctuations reinforcing the role of the global financial cycle for EMEs. Second, the association between EDF and credit surge/stop episodes also points out that the existing prudential and regulatory infrastructure may be inadequate to mitigate the impact of excess debt flows on domestic credit conditions. It may not be effective to moderate the negative impact of EDF stops on the credit cycles in EMEs.

\subsection{Interlinkage of external debt financing, credit and output growth}

In the baseline model, we discuss the impact of credit and EDF flows on GDP growth subject to macroeconomic controls for sample EMEs as given in table 3. Columns (1)-(4) in table 3 present evidence on the impact of credit, EDF and the interaction of credit and EDF on GDP growth, controlling for external and domestic macroeconomic factors. Specification (1) is the basic setup with key variables: EDF flows, credit growth. The interaction and other macroeconomic controls are added to the basic model in specification (2)-(4). We find that a percent increase in credit and EDF flows positively affect GDP growth by $0.5 \%$ and $0.2 \%$ on average respectively. However, the negative coefficient of lagged EDF flows compensates the contemporaneously overshooting (or positive impact).

Further, the impact of lagged interaction of EDF and credit flows is larger than the individual impact of EDF and credit flows. In other words, the combined impact of EDF and credit has an even larger impact on GDP growth. We also observe that the results are robust to the inclusion

8. This paper finds strong empirical evidence that countries with excess capital inflows are more sensitive to global liquidity conditions regardless of domestic monetary policy and exchange rate regime. Our results are on similar lines with more focus on the impact of EDF flows on credit cycles in the context of EMEs 
of domestic and external macroeconomic controls that do not affect the magnitude and the level of significance of key explanatory variables. These results clearly demonstrate that EDF and credit flows have a strong influence over the business cycle in EMEs.

Table 3: Dynamic Panel Model

\begin{tabular}{|c|c|c|c|c|}
\hline & \multicolumn{3}{|c|}{ GDP growth rate as dep. variable } & \multirow[b]{2}{*}{ (4) } \\
\hline & (1) & $(2)$ & $(3)$ & \\
\hline \multirow[t]{2}{*}{ L.GDP growth } & $0.668^{* * *}$ & $0.669^{* * *}$ & $0.662^{* * *}$ & $0.656^{* * *}$ \\
\hline & $(13.74)$ & $(14.08)$ & $(14.35)$ & $(13.49)$ \\
\hline \multirow[t]{2}{*}{ Credit growth } & $0.526^{* *}$ & $0.559^{* *}$ & $0.541^{* *}$ & $0.543^{* *}$ \\
\hline & $(4.56)$ & $(3.93)$ & $(3.91)$ & $(3.95)$ \\
\hline \multirow[t]{2}{*}{ L.Credit growth } & -0.152 & -0.188 & -0.172 & -0.158 \\
\hline & $(-1.39)$ & $(-1.51)$ & $(-1.42)$ & $(-1.31)$ \\
\hline \multirow[t]{2}{*}{ EDF growth } & $0.105^{*}$ & $0.182^{* *}$ & $0.182^{* *}$ & $0.179^{*}$ \\
\hline & $(2.89)$ & $(3.26)$ & $(3.25)$ & $(3.07)$ \\
\hline \multirow[t]{2}{*}{ L.EDF growth } & $-0.112^{*}$ & $-0.195^{* * *}$ & $-0.194^{* * *}$ & $-0.193^{* * *}$ \\
\hline & $(-2.49)$ & $(-5.21)$ & $(-5.00)$ & $(-4.97)$ \\
\hline \multirow[t]{2}{*}{ Credit*EDF (growth) } & & -0.452 & -0.454 & -0.474 \\
\hline & & $(-1.30)$ & $(-1.34)$ & $(-1.43)$ \\
\hline \multirow[t]{2}{*}{ L.Credit*EDF (growth) } & & $0.484^{* *}$ & $0.478^{*}$ & $0.468^{* *}$ \\
\hline & & $(3.19)$ & $(3.14)$ & $(3.44)$ \\
\hline \multirow[t]{2}{*}{$\Delta$ Exchange_rate } & & & $-0.0000548^{* *}$ & $-0.0000562^{* *}$ \\
\hline & & & $(-4.20)$ & $(-4.05)$ \\
\hline \multirow[t]{2}{*}{ L. $\Delta$ Exchange_rate } & & & $-0.0000324^{* * *}$ & $-0.0000336^{* * *}$ \\
\hline & & & $(-6.60)$ & $(-7.25)$ \\
\hline \multirow[t]{2}{*}{ Inflation } & & & & 0.00201 \\
\hline & & & & $(0.60)$ \\
\hline \multirow[t]{2}{*}{ L.Inflation } & & & & -0.000386 \\
\hline & & & & $(-0.11)$ \\
\hline \multirow[t]{2}{*}{ VIX } & $-0.00172^{* *}$ & $-0.00165^{* *}$ & $-0.00150^{* *}$ & $-0.00160^{* *}$ \\
\hline & $(-3.60)$ & $(-4.40)$ & $(-3.77)$ & $(-3.72)$ \\
\hline \multirow[t]{2}{*}{ L.VIX } & 0.000123 & 0.0000504 & -0.0000169 & -0.0000104 \\
\hline & $(0.37)$ & $(0.15)$ & $(-0.05)$ & $(-0.03)$ \\
\hline \multirow[t]{2}{*}{ Post GFC period } & -0.00542 & -0.00529 & -0.00625 & -0.00457 \\
\hline & $(-1.25)$ & $(-1.31)$ & $(-1.63)$ & $(-1.07)$ \\
\hline Obs & 623 & 623 & 623 & 623 \\
\hline Sargan_overid_pval & $1.23 \mathrm{e}-08$ & $1.74 \mathrm{e}-08$ & $5.75 \mathrm{e}-08$ & $5.72 \mathrm{e}-08$ \\
\hline Hansen_overid_pval & 1 & 1 & 1 & 1 \\
\hline ABtest_AR1_pval & 0.00512 & 0.00458 & 0.00468 & 0.00474 \\
\hline ABtest_AR2_pval & 0.170 & 0.123 & 0.0946 & 0.0954 \\
\hline
\end{tabular}

$t$ statistics in parentheses

${ }^{*} p<0.05,{ }^{* *} p<0.01,{ }^{* * *} p<0.001$ 
We extend the analysis to check how credit flows affect GDP growth during EDF surges/stops separately for two reasons - First, we previously demonstrated that EDF surge/stop episodes asymmetrically induce credit cycles in the economy. Second, the combined impact of EDF and credit flows have a magnified impact on the GDP growth of EMEs. We now turn to look into the asymmetric impact of credit growth during the two phases of EDF flows. In the baseline model, we present evidence that a positive increase in credit growth during EDF surges has a strong positive spillover on GDP growth whereas its impact is muted during EDF stops as given in table 4 . This result indicates that credit flows may have a differential impact on the GDP growth rate during different phases of EDF flows which are in turn influenced by external liquidity conditions.

Table 4: Dynamic Panel Model

GDP growth rate as dep. variable

Only EDF surge episodes Only EDF stop episodes

\begin{tabular}{|c|c|c|}
\hline \multirow[t]{2}{*}{ L.GDP growth } & $0.805^{* * *}$ & $0.537^{* * *}$ \\
\hline & $(13.45)$ & $(5.13)$ \\
\hline \multirow[t]{2}{*}{ Credit growth } & $0.153^{* *}$ & 0.483 \\
\hline & $(3.18)$ & $(1.37)$ \\
\hline \multirow[t]{2}{*}{ EDF growth } & $0.0637^{* *}$ & 0.203 \\
\hline & $(3.58)$ & $(1.39)$ \\
\hline \multirow[t]{2}{*}{$\Delta$ Exchange rate } & -0.00567 & $-0.00349^{*}$ \\
\hline & $(-2.19)$ & $(-3.19)$ \\
\hline \multirow[t]{2}{*}{ Inflation } & 0.000755 & -0.00361 \\
\hline & $(0.30)$ & $(-0.31)$ \\
\hline \multirow[t]{2}{*}{ VIX } & $-0.000972^{*}$ & -0.00369 \\
\hline & $(-2.69)$ & $(-1.68)$ \\
\hline \multirow[t]{2}{*}{ Post GFC period } & $-0.0359^{* *}$ & 0.0189 \\
\hline & $(-3.81)$ & $(0.31)$ \\
\hline Obs & 173 & 46 \\
\hline Sargan_overid_pval & 0.141 & 0.164 \\
\hline Hansen_overid_pval & 1 & 1 \\
\hline ABtest_AR1_pval & 0.0371 & 0.518 \\
\hline ABtest_AR2_pval & 0.915 & 0.189 \\
\hline
\end{tabular}


In this part of the analysis, we have dropped the lagged variable as they are insignificant and also because it increases the degrees of freedom in the reduced sample. We also dropped the interaction variable (Credit*EDF) since we attempt to estimate the asymmetric impact of credit growth here and the interaction of credit and EDF is indirectly captured by the estimates of credit in EDF surge and stop episodes respectively. Moreover, our main focus in the following estimations is the impact of credit growth on output growth and inclusion of the interaction does not change the results.

Table 5: Dynamic Panel Model

GDP growth rate as dep. variable

\begin{tabular}{|c|c|c|}
\hline & Only EDF surge episodes & Only EDF stop episodes \\
\hline \multirow[t]{2}{*}{ L.GDP growth } & $0.810^{* * *}$ & $0.521^{* * *}$ \\
\hline & $(12.61)$ & $(8.54)$ \\
\hline \multirow[t]{2}{*}{ Credit growth $(>0)$} & $0.156^{* *}$ & 0.422 \\
\hline & $(3.29)$ & $(1.56)$ \\
\hline \multirow[t]{2}{*}{ Credit growth $(<0)$} & 0.0871 & $-1.226^{* *}$ \\
\hline & $(0.16)$ & $(-3.43)$ \\
\hline \multirow[t]{2}{*}{ EDF growth } & $0.0644^{* *}$ & 0.0901 \\
\hline & $(3.47)$ & $(0.52)$ \\
\hline \multirow[t]{2}{*}{ Inflation } & 0.000739 & 0.0113 \\
\hline & $(0.29)$ & $(0.91)$ \\
\hline \multirow[t]{2}{*}{$\Delta$ Exchange rate } & $-0.00583^{*}$ & -0.00153 \\
\hline & $(-2.68)$ & $(-1.40)$ \\
\hline \multirow[t]{2}{*}{ VIX } & $-0.00111^{*}$ & -0.00475 \\
\hline & $(-2.65)$ & $(-1.57)$ \\
\hline \multirow[t]{2}{*}{ Post GFC period } & $-0.0354^{* *}$ & 0.0551 \\
\hline & $(-3.97)$ & $(1.09)$ \\
\hline Obs & 173 & 46 \\
\hline Sargan_overid_pval & 0.132 & 0.224 \\
\hline Hansen_overid_pval & 1 & 1 \\
\hline ABtest_AR1_pval & 0.0371 & 0.505 \\
\hline ABtest_AR2_pval & 0.878 & 0.163 \\
\hline
\end{tabular}

$t$ statistics in parentheses

${ }^{*} p<0.05,{ }^{* *} p<0.01,{ }^{* * *} p<0.001$ 
Table 4 - Specification (1) shows that a strong impact of credit growth on GDP growth during EDF surge phases. One percent increase in credit growth increases the GDP growth by $0.15 \%$ during surges whereas its impact remains insignificant during EDF stop episodes as shown in specification (2).

All other variables also remain insignificant in the EDF stop case which demonstrates that there no significant association between the explanatory variables (increase in credit growth and EDF growth) and output growth during EDF stop phases. This is not a surprising result if we combine it with results in table 2 which point out that EDF stop episodes are strongly associated with credit stops in EMEs. This also means that economic growth may remain stagnant or decline during such periods in spite of push through credit growth or EDF growth.

However, there still remains the question of whether credit affects output asymmetrically or not during EDF expansion or contraction periods captured through surge/stop episodes. In other words, does credit increase/decrease affect GDP growth similarly in both the phases? To answer this, we estimate a modified model with credit divided into two parts using the model specification given by equation (7) in the methodology section. We find an asymmetric impact of credit growth on output growth as shown in table 5. From the table, it is evident that a 1 $\%$ decrease in credit growth during EDF stops has a relatively larger impact on output growth $(-1.22 \%)$ as opposed to the impact of a $1 \%$ increase in credit growth on output growth $(0.15 \%)$ during EDF surge phase.

This is an interesting result indicating that EDF stops strongly contract the economy in case of a credit decline in this phase and expand the economy during the surges. More importantly, the benefits of EDF surges for the economy are much smaller than the cost incurred during EDF stops.

\subsection{Robustness analysis}

We have conducted robustness analysis for the interlinkages between EDF, credit and output growth. For the baseline model as given in table 3, we have replaced the EDF and output growth with their de-trended part (EDF cycle and output cycle) using a C-F filter and we still find similar results. EDF cycle has a positive and significant impact on the output cycle (GDP cycle) as given in table A.1 in the Appendix. We also conduct a robustness check on the asymmetric impact of credit on output growth during EDF surge and stops. We replaced the dependent variable from GDP growth to GDP cycle and we find that credit decline still 
has a larger impact on the output gap whereas credit increase has a smaller and insignificant impact on the output gap during EDF surges, reinforcing the earlier evidence. Table A.2 in the Appendix provides the results for this case.

\section{Conclusion}

This paper makes an effort to understand the linkages of EDF flows, credit and output growth in the context of EMEs with data samples from pre and post GFC (2008) periods. We first show that surge/stop episodes of credit and EDF flows are strongly linked and that EDF episodes asymmetrically impact the credit surge/stops. EDF stops are relatively more likely to bring about credit stops compared to their counterpart. This mainly has two implications - First, EMEs may incur larger costs due to EDF stop episodes (bust phases) compared to the benefits they may reap during EDF surges. Since EDF flows are typically linked to global liquidity conditions and risk perceptions, EMEs' domestic financial conditions are vulnerable to external conditions. Second, the evidence we present becomes important given the presence of several regulatory measures imposed on EMEs in the form of macroprudential measures and capital controls. They are clearly not effective in discouraging overheating during excess cross border inflows and in absorbing negative shocks during adverse external conditions.

In the second part, we provide empirical evidence that the combined effect of credit and EDF flows is larger in perpetuating the output cycle than their individual/standalone contributions. We also find that credit growth encourages output expansion during EDF surges whereas its impact disappears during EDF stops. If we combine these results with the result from the first part of the analysis, it becomes clear that the association between macroeconomic variables weakens during EDF stops because EDF stops are more likely to bring about credit stops, resulting in an insignificant impact on output growth during this phase. We further find that a credit decline during an EDF stop has a larger negative impact on output growth than that of a credit increase during an EDF surge. Our results also point to a crucial asymmetric role of EDF flows in EMEs; the empirical evidence establishes that benefits from EDF surges are clearly smaller than the losses from EDF stops for the business cycle.

Our results have interesting implications for EMEs in which external debt flows maybe helpful in fulfilling short-term financing needs. Nevertheless, it also results in sharp business cycle fluctuations as a spillover from the financial market to the real economy. Since a credit contraction during EDF stops has an amplified impact on the economy, policymakers need to pay 
more attention to the domestic credit condition during excess debt inflows and outflows and take appropriate measures to mitigate the losses. Since the downside risk of credit cycles are larger on EMEs and because they can get into deeper compared to recessions if global liquidity tightens, EME policymakers must weigh the cost and benefits of EDF flows and manage them through effective regulation to counter their negative spillover on EMEs' business cycle through credit channel. 


\section{References}

Agosin, Manuel R., and Franklin Huaita. 2012. "Overreaction in Capital Flows to Emerging Markets: Booms and Sudden Stops." Journal of International Money and Finance 31 (5): $1140-1155$.

Aguiar, Mark, and Gita Gopinath. 2007. "Emerging Market Business Cycles: The Cycle Is the Trend." Journal of Political Economy 115 (1): 69 -102.

Arellano, Manuel, and Stephen Bond. 1991. "Some tests of specification for panel data: Monte Carlo evidence and an application to employment equations." The Review of Economic Studies 58 (2): 277-297.

Arena, Marco, Serpil Bouza, Era Dabla-Norris, Kerstin Gerling, and Lamin Njie. 2015. Credit Booms and Macroeconomic Dynamics; Stylized Facts and Lessons for Low-Income Countries. IMF Working Papers 15/11. International Monetary Fund.

Avdjiev, Stefan, Stephan Binder, and Ricardo Sousa. 2017. External debt composition and domestic credit cycles. BIS Working Papers 627. Bank of International Settlements.

Azariadis, Costas. 2017. "Credit Cycle and Business Cycle." Review 100 (1).

Bahadir, Berrak, and Inci Gumus. 2016. "Credit Decomposition and Business Cycles in Emerging Market Economies." Journal of International Economics 103:250 -262.

Bakker, Bas B., Giovanni Dell'Ariccia, Luc Laeven, Jérôme Vandenbussche, Deniz O Igan, and Hui Tong. 2012. Policies for Macrofinancial Stability; How to Deal with Credit Booms. IMF Staff Discussion Notes 12/06. International Monetary Fund, June.

Baskaya, Yusuf Soner, Julian Di Giovanni, Şebnem Kalemli-Özcan, José-Luis Peydro, and Mehmet Fatih Ulu. 2017. "Capital flows and the international credit channel." Journal of International Economics 108:S15-S22.

Bernanke, Ben S., and Mark Gertler. 1995. "Inside the Black Box: The Credit Channel of Monetary Policy Transmission." Journal of Economic Perspectives 9 (4): 27 -48.

Borio, Claudio, Robert McCauley, and Patrick McGuire. 2011. "Global Credit and Domestic Credit Booms." BIS Quarterly Review: 43 -57. 
Broner, Fernando A., and Roberto Rigobon. 2006. "Why Are Capital Flows So Much More Volatile in Emerging Than in Developed Countries?." In External Vulnerability and Preventive Policies, 15 -39. CREI, U Pompeu Fabra: Series on Central Banking, Analysis, / Economic Policies, vol. 10. Santiago: Central Bank of Chile.

Bruno, Valentina, and Hyun Song Shin. 2015a. "Capital Flows and the Risk-Taking Channel of Monetary Policy." Journal of Monetary Economics 71:119 -132.

2015b. "Cross-Border Banking and Global Liquidity." Review of Economic Studies 82 (2): $535-564$.

Buttiglione, Luigi, Philip Lane, Lucrezia Reichlin, and Vincent Reinhart. 2014. "Deleveraging, what deleveraging/? The 16th Geneva Report on the world economy." International Center for Monetary and Banking Studies/Center for Economic Policy Research, September.

Calderon, Cesar, and Megumi Kubota. 2012. Gross inflows gone wild: gross capital inflows, credit booms and crises. The World Bank.

Calvo, Guillermo A., Leonardo Leiderman, and Carmen M. Reinhart. 1996. "Inflows of Capital to Developing Countries in the 1990s." Journal of Economic Perspectives 10 (2): 123 -139.

Cecchetti, Stephen G, M. S. Mohanty, and Fabrizio Zampolli. 2011. The real effects of debt. BIS Working Papers 352. Bank of International Settlements.

Cetorelli, Nicola, and Linda S Goldberg. 2011. "Global banks and international shock transmission: Evidence from the crisis." IMF Economic Review 59 (1): 41-76.

Chari, Varadarajan V, Patrick J Kehoe, and Ellen R McGrattan. 2005. "Sudden stops and output drops." American Economic Review 95 (2): 381-387.

Christiano, Lawrence J, and Terry J Fitzgerald. 2003. "The band pass filter." international Economic Review 44 (2): 435-465.

Chui, Michael, Emese Kuruc, and Philip Turner. 2016. A new dimension to currency mismatches in the emerging markets-non-financial companies. BIS Working Papers 550. Bank of International Settlements.

Didier, Tatiana, M Kose, Franziska Ohnsorge, and Lei Sandy Ye. 2016. "Slowdown in emerging markets: rough patch or prolonged weakness?" Washington: World Bank. 
Drehmann, Mathias, Annamaria Illes, Mikael Juselius, and Marjorie Santos. 2015. "How much income is used for debt payments? A new database for debt service ratios."

Edwards, Amy K, Lawrence E Harris, and Michael S Piwowar. 2007. "Corporate bond market transaction costs and transparency." The Journal of Finance 62 (3): 1421-1451.

Eichengreen, Barry, and Carlos Arteta. 2002. "Banking Crises in Emerging Markets: Presumptions and Evidence." In Financial policies in emerging markets, 47 -94. Cambridge / London:

Elekdag, Selim, and Yiqun Wu. 2013. "Rapid credit growth in emerging markets: Boon or boom-bust?" Emerging Markets Finance and Trade 49 (5): 45-62.

Feyen, Erik, Katie Kibuuka, and İnci Ötker-Robe. 2012. Bank deleveraging: causes, channels, and consequences for emerging market and developing countries. The World Bank.

Forbes, Kristin J, and Francis E Warnock. 2012. "Capital flow waves: Surges, stops, flight, and retrenchment." Journal of International Economics 88 (2): 235-251.

Gertler, Mark, and Nobuhiro Kiyotaki. 2010. "Financial intermediation and credit policy in business cycle analysis." In Handbook of Monetary Economics, 3:547-599. Elsevier.

Gourinchas, Pierre Olivier, and Maurice Obstfeld. 2012. "Stories of the twentieth century for the twenty first." American Economic Journal: Macroeconomics 4 (1): 226-65.

Kaminsky, Graciela L., and Carmen M. Reinhart. 1999. "The Twin Crises: The Causes of Banking and Balance-of-Payments Problems." American Economic Review 89 (3): 473 500. ISSN: 00028282.

Kaminsky, Graciela L., Carmen M. Reinhart, and Carlos A. Vegh. 2003. "The Unholy Trinity of Financial Contagion." Journal of Economic Perspectives 17 (4): 51 -74.

— 2005. "When It Rains, It Pours: Procyclical Capital Flows and Macroeconomic Policies." In NBER Macroeconomics Annual 2004, 11 -53. George Washington U: Volume 19.

Khan, Aubhik, and Julia K Thomas. 2013. "Credit shocks and aggregate fluctuations in an economy with production heterogeneity." Journal of Political Economy 121 (6): 10551107.

Kiyotaki, Nobuhiro, and John Moore. 1997. "Credit Cycles." Journal of Political Economy 105 (2): $211-248$. 
Lin, Chien-Hsiu. 2011. "Exchange rate exposure in the Asian emerging markets." Journal of Multinational Financial Management 21 (4): 224-238.

Lo, Stephanie, and Kenneth Rogoff. 2015. Secular stagnation, debt overhang and other rationales for sluggish growth, six years on. BIS Woking Papers 482. Bank of International Settlements.

Meeks, Roland. 2012. "Do Credit Market Shocks Drive Output Fluctuations? Evidence from Corporate Spreads and Defaults." Journal of Economic Dynamics and Control 36 (4): 568 -584 .

Mendoza, Enrique G, and Marco E Terrones. 2008. An anatomy of credit booms: evidence from macro aggregates and micro data. NBER Working Paper 14049. National Bureau of Economic Research.

Mohanty, Madhusudan S, and Kumar Rishabh. 2016. Financial intermediation and monetary policy transmission in EMEs: What has changed post-2008 crisis? BIS Working Papers 546. Bank of International Settlements.

Ohnsorge, Franziska Lieselotte, and Shu Yu. 2016. Recent credit surge in historical context. Policy Research Working Paper Series 7704. The World Bank.

Pena, Diana B Ayala, Milan Nedeljkovic, and Christian Saborowski. 2015. What Slice of the Pie? The Corporate Bond Market Boom in Emerging Economies. IMF Working Papers 15/148. International Monetary Fund, July.

Perri, Fabrizio, and Vincenzo Quadrini. 2018. "International recessions." American Economic Review 108 (4-5): 935-84.

Reinhart, Carmen M, and Kenneth S Rogoff. 2010. "Growth in a Time of Debt." American Economic Review 100 (2): 573-78.

2009. This time is different: Eight centuries of financial folly. Princeton University Press.

Rey, Hélène. 2015. Dilemma not Trilemma: The Global Financial Cycle and Monetary Policy Independence. NBER Working Paper 21162. National Bureau of Economic Research.

Roodman, David. 2015. "xtabond2: Stata module to extend xtabond dynamic panel data estimator." 
Rothenberg, AD, and FE Warnock. 2006. Sudden Flight and True Sudden Stops. NBER Working Papers 12726. International Monetary Fund.

Schularick, Moritz, and Alan M. Taylor. 2012. "Credit Booms Gone Bust: Monetary Policy, Leverage Cycles, and Financial Crises, 1870-2008." American Economic Review 102 (2): 1029 -1061. ISSN: 00028282.

Shin, Hyun Song. 2014. "The second phase of global liquidity and its impact on emerging economies." In Volatile Capital Flows in Korea, 247-257. Springer.

Sula, Ozan. 2010. "Surges and Sudden Stops of Capital Flows to Emerging Markets." Open Economies Review 21 (4): $589-605$.

Tornell, Aaron, and Frank Westermann. 2002. "Boom-bust cycles in middle income countries: Facts and explanation." IMF Staff Papers 49 (1): 111-155.

Tornell, Aaron, Frank Westermann, and Lorenza Martinez. 2003. "Liberalization, growth, and financial crises: Lessons from Mexico and the developing world." Brookings Papers on Economic Activity 2003 (2): 1-112. 


\section{A Appendix}

\section{A.1 Robustness checks: Regression results}

Table A.1: Dynamic Panel Model

\begin{tabular}{|c|c|c|c|c|c|}
\hline & \multicolumn{5}{|c|}{ GDP-cycle (output gap) as dep. variable } \\
\hline & (1) & $(2)$ & $(3)$ & $(4)$ & $(5)$ \\
\hline \multirow[t]{2}{*}{ L.GDP cycle $(\mathrm{CF})$} & $0.796^{* * *}$ & $0.794^{* * *}$ & $0.792^{* * *}$ & $0.792^{* * *}$ & $0.788^{* * *}$ \\
\hline & $(24.75)$ & $(22.64)$ & $(22.08)$ & $(22.08)$ & $(20.85)$ \\
\hline \multirow[t]{2}{*}{$\mathrm{EDF}$ cycle $(\mathrm{CF})$} & $0.136^{*}$ & $0.216^{*}$ & $0.215^{*}$ & $0.215^{*}$ & $0.211^{*}$ \\
\hline & $(2.30)$ & $(2.49)$ & $(2.51)$ & $(2.51)$ & $(2.42)$ \\
\hline \multirow[t]{2}{*}{ Credit growth } & $0.0601^{* *}$ & $0.0608^{*}$ & $0.0593^{* *}$ & $0.0593^{* *}$ & $0.0576^{* *}$ \\
\hline & $(3.33)$ & $(3.23)$ & $(3.32)$ & $(3.32)$ & $(3.68)$ \\
\hline \multirow[t]{2}{*}{ L.Credit growth } & $-0.0718^{*}$ & $-0.0756^{*}$ & $-0.0756^{*}$ & $-0.0756^{*}$ & $-0.0730^{*}$ \\
\hline & $(-2.62)$ & $(-2.76)$ & $(-2.76)$ & $(-2.76)$ & $(-2.49)$ \\
\hline \multirow[t]{2}{*}{ L.EDF cycle $(\mathrm{CF})$} & -0.104 & -0.139 & -0.142 & -0.142 & -0.145 \\
\hline & $(-1.89)$ & $(-1.39)$ & $(-1.45)$ & $(-1.45)$ & $(-1.49)$ \\
\hline \multirow[t]{2}{*}{$\Delta$ Exchange rate } & $-0.00190^{*}$ & $-0.00178^{*}$ & $-0.00184^{*}$ & $-0.00184^{*}$ & $-0.00185^{*}$ \\
\hline & $(-3.07)$ & $(-2.81)$ & $(-2.91)$ & $(-2.91)$ & $(-2.77)$ \\
\hline \multirow[t]{2}{*}{ L. $\Delta$ Exchange rate } & $-0.00205^{* *}$ & $-0.00204^{* *}$ & $-0.00208^{* *}$ & $-0.00208^{* *}$ & $-0.00213^{* *}$ \\
\hline & $(-4.20)$ & $(-3.91)$ & $(-4.17)$ & $(-4.17)$ & $(-3.97)$ \\
\hline \multirow[t]{2}{*}{ VIX } & $-0.000566^{*}$ & $-0.000730^{* *}$ & $-0.000681^{* *}$ & $-0.000681^{* *}$ & $-0.000682^{* *}$ \\
\hline & $(-2.38)$ & $(-3.59)$ & $(-3.67)$ & $(-3.67)$ & $(-3.53)$ \\
\hline \multirow[t]{2}{*}{ L.VIX } & -0.0000894 & 0.00000485 & 0.0000303 & 0.0000303 & 0.000115 \\
\hline & $(-0.46)$ & $(0.02)$ & $(0.15)$ & $(0.15)$ & $(0.53)$ \\
\hline \multirow[t]{2}{*}{ Post GFC period } & 0.00163 & 0.00167 & 0.00142 & 0.00142 & -0.00151 \\
\hline & $(1.34)$ & $(1.07)$ & $(0.89)$ & $(0.89)$ & $(-1.08)$ \\
\hline \multirow[t]{2}{*}{ Short term interest rate } & & -0.000828 & -0.000810 & -0.000810 & -0.000785 \\
\hline & & $(-0.75)$ & $(-0.75)$ & $(-0.75)$ & $(-0.73)$ \\
\hline \multirow[t]{2}{*}{ L.Short term interest rate } & & 0.000641 & 0.000914 & 0.000914 & 0.000838 \\
\hline & & $(0.99)$ & $(1.22)$ & $(1.22)$ & $(1.10)$ \\
\hline \multirow[t]{2}{*}{ Inflation } & & & 0.00118 & 0.00118 & 0.00129 \\
\hline & & & $(1.34)$ & $(1.34)$ & $(1.52)$ \\
\hline L.Inflation & & & -0.00168 & -0.00168 & -0.00157 \\
\hline
\end{tabular}



$(-1.54)$
$(-1.54)$
$(-1.65)$

Reserves

0.0000841

$(0.98)$

L.Reserves

$-0.0000506$

\begin{tabular}{lccccc} 
& \multicolumn{1}{c}{$(-0.58)$} \\
\hline Obs & 619 & 557 & 557 & 557 & 557 \\
Sargan_overid_pval & 0.309 & 0.352 & 0.329 & 0.329 & 0.308 \\
Hansen_overid_pval & 1 & 1 & 1 & 1 & 1 \\
ABtest_AR1_pval & 0.194 & 0.272 & 0.290 & 0.290 & 0.312 \\
ABtest_AR2_pval & 0.00587 & 0.00989 & 0.0107 & 0.0107 & 0.0109 \\
\hline \hline
\end{tabular}

$t$ statistics in parentheses

${ }^{*} p<0.05,{ }^{* *} p<0.01,{ }^{* * *} p<0.001$

Table A.2: Dynamic Panel Model

\begin{tabular}{|c|c|c|}
\hline & \multicolumn{2}{|c|}{ GDP-cycle (output gap) as dep. variable } \\
\hline & $(1)$ & $(2)$ \\
\hline & Only EDF surge episodes & Only EDF stop episodes \\
\hline \multirow[t]{2}{*}{ L.GDP cycle(CF) } & $0.767^{* * *}$ & $0.469^{* * *}$ \\
\hline & $(28.54)$ & $(8.13)$ \\
\hline \multirow[t]{2}{*}{ Credit growth $(>0)$} & 0.0341 & 0.0160 \\
\hline & $(1.15)$ & $(0.35)$ \\
\hline \multirow[t]{2}{*}{ Credit growth $(<0)$} & -0.339 & $-0.450^{* * *}$ \\
\hline & $(-1.18)$ & $(-5.69)$ \\
\hline \multirow[t]{2}{*}{ EDF growth } & $0.0450^{*}$ & -0.00734 \\
\hline & $(3.15)$ & $(-0.20)$ \\
\hline \multirow[t]{2}{*}{ Inflation } & -0.00132 & 0.00711 \\
\hline & $(-1.43)$ & $(2.26)$ \\
\hline \multirow[t]{2}{*}{$\Delta$ Exchange rate } & $-0.00273^{*}$ & -0.0000692 \\
\hline & $(-3.02)$ & $(-0.15)$ \\
\hline \multirow[t]{2}{*}{ VIX } & 0.0000620 & -0.00237 \\
\hline & $(0.19)$ & $(-1.91)$ \\
\hline \multirow[t]{2}{*}{ Post GFC period } & $-0.0131^{*}$ & 0.0343 \\
\hline & $(-2.35)$ & $(1.65)$ \\
\hline Obs & 173 & 44 \\
\hline Sargan_overid_pval & 0.293 & 0.710 \\
\hline Hansen_overid_pval & 1 & 1 \\
\hline
\end{tabular}




\begin{tabular}{lcc} 
ABtest_AR1_pval & 0.590 & 0.0718 \\
ABtest_AR2_pval & 0.00880 & 0.916 \\
\hline \hline$t$ statistics in parentheses & \\
${ }^{*} p<0.05,{ }^{* *} p<0.01,{ }^{* * *} p<0.001$ &
\end{tabular}

\section{A.2 Surge and stop episodes of credit and EDF flows for sample EMEs}

Table A.3: Credit surges

\begin{tabular}{ccc}
\hline \hline \multirow{2}{*}{ Country } & \multicolumn{2}{c}{ Credit surge episodes } \\
\cline { 2 - 3 } & Start-period & Stop-period \\
\hline Brazil & & \\
& $06 / 30 / 2005$ & $12 / 31 / 2006$ \\
& $09 / 30 / 2007$ & $09 / 30 / 2008$ \\
& $03 / 31 / 2010$ & $06 / 30 / 2011$ \\
& $12 / 31 / 2016$ & $09 / 30 / 2017$ \\
\hline Chile & & \\
& $09 / 30 / 2004$ & $06 / 30 / 2006$ \\
& $12 / 31 / 2007$ & $09 / 30 / 2008$ \\
& $09 / 30 / 2010$ & $09 / 30 / 2011$ \\
& $12 / 31 / 2012$ & $06 / 30 / 2013$ \\
\hline
\end{tabular}

\section{China}

\begin{tabular}{ccc} 
& $06 / 30 / 2002$ & $09 / 30 / 2004$ \\
& $06 / 30 / 2006$ & $09 / 30 / 2014$ \\
\hline India & & \\
& $03 / 31 / 2000$ & $12 / 31 / 2000$ \\
& $09 / 30 / 2002$ & $03 / 31 / 2006$ \\
& $03 / 31 / 2007$ & $06 / 30 / 2008$ \\
& $06 / 30 / 2010$ & $06 / 30 / 2011$ \\
& $03 / 31 / 2017$ & $09 / 30 / 2017$ \\
\hline Indonesia & & \\
& $06 / 30 / 2008$ & $12 / 31 / 2008$ \\
& $03 / 31 / 2010$ & $03 / 31 / 2012$ \\
& $09 / 30 / 2016$ & $06 / 30 / 2017$ \\
\hline
\end{tabular}


Table A.3: (continued)

\begin{tabular}{ccc}
\hline \multirow{2}{*}{ Country } & \multicolumn{2}{c}{ Credit surge episodes } \\
\cline { 2 - 3 } & Start-period & Stop-period \\
\hline Malaysia & & \\
& $12 / 31 / 2004$ & $12 / 31 / 2008$ \\
& $03 / 31 / 2010$ & $09 / 30 / 2011$ \\
\hline Mexico & & \\
& $06 / 30 / 2005$ & $09 / 30 / 2008$ \\
\hline Russia & & \\
& $06 / 30 / 2006$ & $12 / 31 / 2008$ \\
\hline South Africa & & \\
& $03 / 31 / 2003$ & $12 / 31 / 2004$ \\
& $03 / 31 / 2010$ & $06 / 30 / 2011$ \\
& $12 / 31 / 2016$ & $09 / 30 / 2017$ \\
\hline Thailand & & \\
& $12 / 31 / 2006$ & $03 / 31 / 2008$ \\
& $09 / 30 / 2010$ & $09 / 30 / 2011$ \\
\hline
\end{tabular}

Table A.4: Credit stops

\begin{tabular}{ccc}
\hline \hline \multirow{2}{*}{ Country } & \multicolumn{2}{c}{ Credit stop episodes } \\
\cline { 2 - 3 } & Start-period & Stop-period \\
\hline \multirow{2}{*}{ Brazil } & & \\
& $03 / 31 / 2009$ & $09 / 30 / 2009$ \\
& $06 / 30 / 2012$ & $03 / 31 / 2013$ \\
& $03 / 31 / 2015$ & $03 / 31 / 2016$ \\
\hline Chile & & \\
& $03 / 31 / 2009$ & $09 / 30 / 2009$ \\
& $03 / 31 / 2014$ & $12 / 31 / 2015$ \\
\hline China & & \\
& $06 / 30 / 2016$ & $09 / 30 / 2017$ \\
\hline India & & \\
& $03 / 31 / 2009$ & $09 / 30 / 2009$ \\
\hline
\end{tabular}


Table A.4: (continued)

\begin{tabular}{|c|c|c|}
\hline \multirow[t]{2}{*}{ Country } & \multicolumn{2}{|c|}{ Credit stop episodes } \\
\hline & Start-period & Stop-period \\
\hline \multicolumn{3}{|l|}{ Indonesia } \\
\hline & $12 / 31 / 2013$ & $09 / 30 / 2014$ \\
\hline & $09 / 30 / 2015$ & $12 / 31 / 2015$ \\
\hline \multicolumn{3}{|l|}{ Malaysia } \\
\hline & $03 / 31 / 2015$ & $06 / 30 / 2016$ \\
\hline \multicolumn{3}{|l|}{ Mexico } \\
\hline & $03 / 31 / 2003$ & $03 / 31 / 2003$ \\
\hline & 03/31/2009 & $12 / 31 / 2009$ \\
\hline & $03 / 31 / 2015$ & 06/30/2016 \\
\hline \multicolumn{3}{|l|}{ Russia } \\
\hline & $06 / 30 / 2009$ & $03 / 31 / 2010$ \\
\hline & $12 / 31 / 2014$ & $03 / 31 / 2016$ \\
\hline \multicolumn{3}{|c|}{ South Africa } \\
\hline & $12 / 31 / 2000$ & $09 / 30 / 2002$ \\
\hline & $09 / 30 / 2008$ & $09 / 30 / 2009$ \\
\hline & $06 / 30 / 2012$ & 09/30/2012 \\
\hline & $09 / 30 / 2013$ & $06 / 30 / 2014$ \\
\hline \multicolumn{3}{|l|}{ Thailand } \\
\hline & $12 / 31 / 2008$ & $09 / 30 / 2009$ \\
\hline & $06 / 30 / 2014$ & $06 / 30 / 2016$ \\
\hline
\end{tabular}


Table A.5: EDF surges

\begin{tabular}{|c|c|c|}
\hline \multirow[t]{2}{*}{ Country } & \multicolumn{2}{|c|}{ EDF surge episodes } \\
\hline & Start-period & Stop-period \\
\hline \multicolumn{3}{|l|}{ Brazil } \\
\hline & $03 / 31 / 2007$ & $12 / 31 / 2008$ \\
\hline & 09/30/2010 & $03 / 31 / 2012$ \\
\hline \multicolumn{3}{|l|}{ Chile } \\
\hline & $06 / 30 / 2003$ & $06 / 30 / 2004$ \\
\hline & $03 / 31 / 2008$ & $03 / 31 / 2009$ \\
\hline & $06 / 30 / 2010$ & $12 / 31 / 2011$ \\
\hline \multicolumn{3}{|l|}{ China } \\
\hline & $06 / 30 / 2003$ & $12 / 31 / 2005$ \\
\hline & $12 / 31 / 2007$ & $12 / 31 / 2008$ \\
\hline & 09/30/2010 & $03 / 31 / 2012$ \\
\hline & $12 / 31 / 2013$ & $12 / 31 / 2014$ \\
\hline \multicolumn{3}{|l|}{ India } \\
\hline & $06 / 30 / 2003$ & $12 / 31 / 2008$ \\
\hline \multicolumn{3}{|l|}{ Indonesia } \\
\hline & $06 / 30 / 2003$ & $03 / 31 / 2007$ \\
\hline & 09/30/2007 & 09/30/2008 \\
\hline & 09/30/2010 & $03 / 31 / 2012$ \\
\hline & $09 / 30 / 2013$ & $06 / 30 / 2015$ \\
\hline & $12 / 31 / 2015$ & 09/30/2016 \\
\hline \multicolumn{3}{|l|}{ Malaysia } \\
\hline & $09 / 30 / 2002$ & 09/30/2003 \\
\hline & 09/30/2005 & $06 / 30 / 2006$ \\
\hline & $06 / 30 / 2008$ & 09/30/2008 \\
\hline \multicolumn{3}{|l|}{ Mexico } \\
\hline & $09 / 30 / 2006$ & $12 / 31 / 2008$ \\
\hline & 09/30/2010 & $12 / 31 / 2011$ \\
\hline & $06 / 30 / 2014$ & $03 / 31 / 2015$ \\
\hline
\end{tabular}


Table A.5: (continued)

\begin{tabular}{ccc}
\hline \multirow{2}{*}{ Country } & \multicolumn{2}{c}{ EDF surge episodes } \\
\cline { 2 - 3 } Russia & Start-period & Stop-period \\
\hline & $12 / 31 / 2003$ & $12 / 31 / 2006$ \\
& $06 / 30 / 2007$ & $09 / 30 / 2008$ \\
& $03 / 31 / 2013$ & $12 / 31 / 2013$ \\
\hline South Africa & & \\
& $03 / 31 / 2003$ & $03 / 31 / 2004$ \\
& $03 / 31 / 2006$ & $06 / 30 / 2008$ \\
\hline Thailand & & \\
& $09 / 30 / 2004$ & $09 / 30 / 2006$ \\
& $09 / 30 / 2010$ & $12 / 31 / 2011$ \\
& $06 / 30 / 2013$ & $06 / 30 / 2014$ \\
\hline
\end{tabular}

Table A.6: EDF stops

\begin{tabular}{|c|c|c|}
\hline \multirow[t]{2}{*}{ Country } & \multicolumn{2}{|c|}{ EDF stop episodes } \\
\hline & Start-period & Stop-period \\
\hline \multicolumn{3}{|l|}{ Brazil } \\
\hline & $03 / 31 / 2005$ & $09 / 30 / 2005$ \\
\hline & $12 / 31 / 2015$ & $03 / 31 / 2017$ \\
\hline \multicolumn{3}{|l|}{ Chile } \\
\hline & $12 / 31 / 2016$ & $03 / 31 / 2017$ \\
\hline \multicolumn{3}{|l|}{ China } \\
\hline & $03 / 31 / 2009$ & $12 / 31 / 2009$ \\
\hline & $06 / 30 / 2015$ & $12 / 31 / 2016$ \\
\hline \multicolumn{3}{|l|}{ India } \\
\hline & 09/30/2009 & $03 / 31 / 2010$ \\
\hline \multicolumn{3}{|l|}{ Indonesia } \\
\hline & 06/30/2009 & 09/30/2009 \\
\hline \multicolumn{3}{|l|}{ Malaysia } \\
\hline & $03 / 31 / 2009$ & $03 / 31 / 2010$ \\
\hline & $09 / 30 / 2015$ & $12 / 31 / 2016$ \\
\hline
\end{tabular}


Table A.6: (continued)

\begin{tabular}{ccc}
\hline Country & \multicolumn{2}{c}{ EDF stop episodes } \\
\cline { 2 - 3 } & Start-period & Stop-period \\
\hline Mexico & & \\
& $06 / 30 / 2002$ & $06 / 30 / 2004$ \\
\hline Russia & & \\
& $06 / 30 / 2009$ & $12 / 31 / 2010$ \\
& $12 / 31 / 2014$ & $03 / 31 / 2016$ \\
\hline South Africa & & \\
& $03 / 31 / 2009$ & $12 / 31 / 2009$ \\
\hline Thailand & & \\
& $12 / 31 / 2014$ & $03 / 31 / 2016$ \\
\hline
\end{tabular}

